\title{
A ASEMBLEA DE ZARAGOZA E A ORGANIZACIÓN POLÍTICO-ADMINISTRATIVA DE ESPAÑA E DE GALICIA EN 1898
}

\author{
por \\ BALDOMERO CORES TRASMONTE
}

I

\section{AS CLASES PRODUCTORAS E A ESPAÑA DERROTADA}

A Asemblea de Cámaras de Comercio, Industria e Navegación, celebrada en Zaragoza entre os días 20 e 27 de novembro de 1898, despertou unha gran expectación e moitas esperanzas nunha España moralmente derrotada. Entre os movementos que tentaron de conxurala críse profunda que vivía o pobo español nos derradeiros anos do século XIX, pode mencionarse o iniciado polas Cámaras, inspirado, básicamente, nunha asunción práctica do credo rexeneracionista. As que se chamaban a si mesmas clases productoras, coma algunhas entidades agrarias, tentaron de reaccionar contra a críse integral que, en ordes coma o político, o cultural ou o partidista, vivía a sociedade daquel momento. Non faltaban os que coidaban que o mal viña de moi lonxe, como Moreno Barcia, na reunión da Cámara da Coruña, celebrada o día 14 de novembro de 1898, xa que arrincou de Carlos I, pero os males acentuáronse coa derrota militar en 1898 e coa presencia do que algún chamou a chegada dos mártires, unha carga de moribundos, un osario de soldados, que baixaba dos barcos que os cuspian 
nos peiraos da Coruña e de Vigo, en Galicia, ou tamén en Cádiz, Santander e outros portos nostiveron que vivila presencia dos calificados como sanguiñentos despoxos ${ }^{1}$.

En outubro de 1898, a Cámara de Cartaxena lanzou a consigna para a renexeración da vida española. As demáis cámaras acudiron á chamada, acordando xuntarse en Zaragoza nunha magna asemblea, que tivo gran repercusión na época e que será coma o xérmolo da Liga de Productores e da Unión Nacional. En sesión do día 4 de novembro de 1898, o presidente da Cámara compostelá expuxo á consideración da directiva «la gran corriente de solidaridad que se advertía en las Cámaras de Comercio en pro de la idea iniciada por la de Cartagena para que se celebre una Asamblea general de todos esos organismos económico- mercantiles. Manifiesta igualmente que ante los peligros que la Patria atraviesa, sería conveniente pensar en la necesidad de ayudar a las demás hermanas, a fín de lograr que el Gobierno prestase la debida atención a peticiones tan justas cuanto deseadas, como la reorganización de los servicios públicos, reducción de los enormes gastos que superficialmente soporta el Estado y planteamiento de un sistema que moralice la Administración pública». E continúa: «despues de varias consideraciones expuestas por los señores Carro, Villar, Lorenzo, Luengo y Martínez se acordó adherirse a la propuesta por la Cámara de Cartagena y procurar por todos los medios posibles enviar a la Asamblea de Zaragoza cumplida representación, dando la importancia y trascendencia que ha de tener aquella reunión convendría que fuese en una de las capitales del centro de la Península, viendo con gusto se designase a Zaragoza, por haberse así indicado por otras Cámaras»» ${ }^{2}$.

O Goberno estaba moi preocupado polo que podía resultar do movemento cameralista de Zaragoza. Un artigo de Moret, como deputado por Zaragoza, publicado no Heraldo de Aragón, deixaba constancia nidia das cautelas con que o Goberno miraba aquel movemento, inspirado fundamentalmente por Xoaquín Costa e encarnado en Basilio Paraíso, presidente da Cámara anfitriona. A opinión pública comenzaba a establecer unha diferencia entre o parlamento real, que miraba cara Zaragoza, e o parlamento

\footnotetext{
'Baldomero CORES TRASMONTE: Un modelo politico para España e para Galicia. A proposta da Cámara de Comercio de Santiago para unha acción rexeneracionista despois do desastre de 1898. Revista da Federación Galega de Municipios e Provincias. Santiago, número 5, verán 1994, pp. 29-38.

${ }^{2}$ Cámara Oficial de Comercio de Santiago. Libro de Actas da Xunta directiva, p. 69.
} 
oficial, secuestrado polas oligarquías dominantes. Na primeira sesión da Asemblea, algúns asistentes tomaron as palabras de Moret como unha provocación, xa que lles dicía que se meteran máis ben en cousas da súa incumbencia, pero, ó final, evitouse calquera resposta expresa.

As Cámaras galegas enviaron delegados e interviron activamente tanto nos actos preliminares como logo durante a Asemblea. A Cámara da Coruña enviou a Xosé López Trigo, Nicandro Fariña e Ulpiano Galindo; a de Lugo deputou a Lourenzo García e a Xosé Carro; a de Vigo a Xosé Ramón Curbera, Fernando Conde, Ventura Sanjurjo e Xoaquín Pérez Boullosa, que foi, logo, elixido secretario da Mesa. A de Santiago pretendiu designar o día 9 de novembro de 1898 a Lucas de la Riva, que era o seu presidente, e a Acisclo Sáez, pero ningún dos dous aceptou. De novo, o día 16 volveron a ser nomeados os dous, pero, ó manterse na mesma postura Sáez, foron nomeados de la Riva e Xosé Luengo. Antes do Congreso tiveron contactos, xa no tren, cos delegados de Asturias, para facer un fronte común con respecto ó problema do millo, e xa, durante o Congreso tiveron unha participación activa, sobre todo nas Comisións ${ }^{3}$.

A Cámara compostelá aprobou o día 16 de novembro un documento, a modo de proposta de conclusións, partindo dun cuestionario elaborado pola Cámara de Cartaxena ${ }^{4}$. O modelo organizativo da Cámara de Santiago non é unha proposta estrictamente galega, pensada exclusivamente para Galicia, senón un modelo de organización política de España, baixo a ideoloxía rexeneracionista. A intención dos cameralistas era facer unha proposta de acción para as chamadas clases productivas. No seu breve limiar indica que tales conclusións están «inspiradas no solamente en el bien general de España, sino en el especial del país gallego, que representa en unión con las demás Cámaras regionales». A Cámara está interesada en «las reformas que deben introducirse en la administración general del Estado para restaurar á España, y salvarla de una total ruina en el caso de continuar el régimen gubernativo existente» desde unha perspectiva reformista, sen afectala lexitimidade do sistema ou do réxime e a continuidade das estructuras básicas do goberno ${ }^{5}$.

\footnotetext{
${ }^{3} \mathrm{Os}$ feitos e acontecementos dos que non se especifique a fonte están tomados da Gaceta de Galicia e do Eco de Santiago, de Santiago, e de La Voz de Galicia, da Coruña.

${ }^{4}$ Cámara Oficial de Comercio de Santiago. Libro de Actas das Xuntas Xerais, $16-$ $\mathrm{X} 1-98$.

${ }^{5}$ Non se encontra nos arquivos da Cámara de Comercio de Santiago a proposta feita polos seus membros. Recollémola do "Eco de Galicia", da Habana.
}

"CUAdernos DE eStUdios GALlEGOS", Tomo XLII, Fascículo 107, Santiago 1995. 
No mesmo limiar faise unha protesta leal e sinceira, sinalando que non está inspirada por ningún ideal político, non se fundan no programa de ningún home parlamentario e non atende intereses de ningún partido, nin segue as pegadas de ninguén: «El objetivo de la Cámara compostelana es aportar un grano de arena á la gran obra de las Cámaras de Comercio españolas, es colaborar humildemente en esta Asamblea y ofrecer su concurso para lograr la salvación de la patria».

Tomando como unidade de análise a cámara compostelá, a súas fontes de inspiración para as conclusións poden ser internas ou externas. Entre as externas, algunhas fóran anunciadas con algunha anticipación e en circunstancias moi diferentes. O Manifesto de Camilo G. Polavieja, datado o día 1 de setembro de 1898, pode servir para explicalo ambiente reinante. Aínda que saíu moi estratéxicamente o día 13 de novembro de 1898, tres días antes da publicación das conclusións compostelás e seis antes da inauguración da Asemblea, causou impacto nos ambientes cameralistas, por suposto, o programa da Cámara Agrícola do Alto Aragón, inspirado por Xoaquín Costa, sintentizando as políticas nunha política reductora ou simplificadora, sumarísima, modesta, reparadora, tradicionalista.

Pero, para entender axeitadamente o sentido das conclusións da Cámara de Comercio de Santiago, existe unha fonte moi concreta, como é a Exposición remitida pola Cámara á Raíña o día 9 de setembro de 1898 , que pode completarse con outro escrito elevado o 16 de xullo ó presidente do Consello de Ministros, no que se referían á loita desigual, e tentaban de «buscar la ansiada fórmula que salvando el honor de España rehabilite la vida nacional», e no que falaban, concretamente, de cando se agravou o conflicto «con la amenaza de un ataque a nuestras costas $»^{6}$. Na Exposición dicían: «Renuncia esta Corporación a consideraciones referentes al origen de la guerra, su desarrollo y resultado fatal para nuestras armas y reserva a la Historia su fallo que, será, seguramente tan inexorable cual es la condenación que hoy hace el país». Tamén engadían que «ahora perdido el resto de nuestro dilatado imperio colonial tiene obligación de subordinar los gastos a la modesta situación en que quedamos reducidos, sacrificando en aras de la Patria las esplendideces burocráticas».

${ }^{6}$ Cámara de Comercio: Libro copiador de correspondencia, 7 de outubro de 1898 , pp. 242-245.

"CUADERNOS DE ESTUdIOS GALLEGOS", Tomo XLII, Fascículo 107, Santiago 1995. 
A Cámara expón un cadro moi negro de Galicia, non exento de algún tópico: «Galicia no se alzará seguramente contra las nuevas exacciones: es amante del orden, pero, desalentados sus habitantes emigrarán en masa a otros países, sin que nos queda la esperanza de que vuelvan porque llevan grabada en el alma las injusticias de nuestra administración», sinalando que «son alarmantes los progresos que esta idea hace en la población rural». E segue ampliando esta descrición: «Es un hecho desgraciadamente cierto Señora: el pueblo español hállase empobrecido y arruinado y como si no bastase tanto infortunio, miles de sus hijos, deseminados por toda la península con su existencia minada por gérmen mortal, extenuados y faltos de fuerzas para el trabajo y de recursos para su curación...», para pasar a explicar os problemas económicos da crise.

A conclusión global non podía ser outra: «Ya no es solo el presente aflictivo lo que inquieta, es también ún porvenir de ruína, es el ánimo contristado y el espíritu desfallecido ante tan gigantesca lucha a punto de rendirse por la fuerza de abrumadora pesadumbre». A intensidade do mal estaba descrita: «El mal Señora es tan hondo como grave: tan arraigado cuanto mortal. Exige grandes reactivos, perseverancia y energía». E concreta: «Espíritus soñadores, eminencias ficticias; economistas al azar, podrán encontrar medios de salvar momentaneamente las que dificultades que surjan y entorpecen su camino; pero, al hacerlo así, comprometen y agravan los medios de producción del país».

\section{AS PROPOSTAS E AS CONCLUSIÓNS DA ASEMBLEA}

O documento da Cámara de Comercio de Santiago consta de medio cento de propostas de conclusións para Asemblea, divididas en varias rúbricas, distribuídas entre 5 de reformas políticas, 7 de reformas administrativas, 7 de reformas militares, 8 de reformas xudiciais, 3 de reformas do ensino, 5 de reformas económicas e 15 de reformas de facenda. A separación entre elas non sempre é demasiado precisa, porque algunhas poden incluírse noutros aportados ou en máis de un, coma os referentes á órganización. Non existe unha sistemática moi precisa sobre as funcións administrativas, xa que non sempre se distinguen entre servicio público, fomento ou policía. A sistemática cambia algo con respecto ás Conclusións aprobadas na Asemblea de Zaragoza, xa que á primeira refírese á reorganización política e administrativa, a segunda a Facenda, a terceira a Fomento, a cuarta a Xusticia e a quinta a Guerra e Mariña. Ollemos con algún detalle cada un dos apartados: 
a) As reformas militares e a decadencia española.

No apartado adicado ás reformas militares, a proposta dos cameralistas compostelás afirma a necesidade do servicio militar obrigatorio, a reforma do cadro de exencións físicas e legais, a clausura das academias militares e da Armada, mentras existan excedentes de oficiais; a amortización de prazas de oficiais xerais, formación dun presuposto para atender ós mutilados das campañas coloniais, reducción do contixente activo, execución por subhasta das obras públicas militares, arrendo dos asteleiros e arsenais a empresas particulares e fixación de cadros de persoal limitadas, e prohibición de fixala dotación dos buques ata que estiveran en prohibición de fixala dotación dos buques ata que estiveran en condicións de navegar.

A derrota do exército español na Guerra hispano-americana colocou os problemas militares do primeiro plano da atención dos españois. A conciencia de crise vivida polos españois con motivo da perda das colonias, dos derradeiros vestixios do imperio español, afectou dun xeito moi directo á organización militar e ó papel do exército na vida española. Os seus problemas, organizativos, formas de reclutamento, financiamento, respecto de dereitos fóron motivo de atención pública. As reformas militares e o papel do exército formarán parte das distintas propostas de rexeneración da vida española en calquera das súas dimensións públicas.

Pero, desde Galicia puideron percibirse outros problemas máis profundos, vividos directamente, con cadros macabros, nos que as ideoloxías se convertían en piedade. Desde Galicia os problemas militares tiñan unha dimensión persoal moi dramática. O deprimente espectáculo dos repatriados vencidos psicolóxica, moral e físicamente arrepiaba os sentimentos e as actitudes mais sereas cando poñían por vez primeira os seus pes en territorio español. Cando atracaban nos portos da Coruña ou de Vigo o Alicante, o Monserrat, o San Ignacio de Loyola, o Saint Cugat, o Notre Dame de la Santé, o Montevideo, e ceibaban civís atemorizados, soldados mutilados, pobres, mal vestidos, as dimensións ideolóxicas facíanse máis profundas e a situación de impotencia facíase máis visible. Malia das advertencias do xeral Blanco, para que se fixera gradualmente a evacuación, os retrasos incomodaron ó exército americano, o que obrigou logo a unha saída precipitada, que se notou cando os barcos empezaron a atracar nos muelles galegos e de outros puntos do litoral.

A presencia dos soldados polas rúas coruñesas foi obxecto de máis dun altercado. Na praza de abastos, as vendedoras puxeron pratiños no chan, para que as xentes caritativas socorreran ós soldados, pero a presencia dun capitán, enviado polo comandante da praza, estivo a punto de crear un 
conflicto. Houbo acusacións de febre marela. O hospital militar quedou pequeno para atender a tanto mutilado e houbo que improvisar outro privisoriamente. Os trens-hospitais poñían unha nota aínda máis doente entre tanta miseria e tanta desventura.

Na Exposición elevada á Raíña pola Cámara de Santiago o día 9 de outubro de 1898, xa deixou constancia dos problemas: «Lamenta sí la forma como se repatrian nuestros soldados y como se devuelve esa juventud a sus humildes hogares, enfermos desvalidos y sin el socorro a que tienen derecho». Nas conclusión que a Cámara presentou á Asemblea de Zaragoza referíase a este aspecto humano: «Formación dun presuposto especial para atender ós inutilizados nas campañas das últimas guerras coloniais e internacionais». Non pasou ás conclusións da Asemblea.

Dentro do marco do servicio militar obrigatorio, así formulado sen máis precisións, significaba un pronunciamento indirecto contra a redención a metálico do tributo de sangue. No mes de setembro, nas Cortes, existía a idea xa formulada, polo que as conclusións compostelás non eran novas, senón máis ben un reforzo sen outras precisións. A purificación económica da vida militar e as formas de reclutamento dos mandos tamén preocupaba. A Asemblea, finalmente, expresou en forma máis tallante a obrigatoriedade do servicio militar, porque engadía «sin redención ni sustitución».

A segunda referíase a reorganización completa dos servicios do exército e da mariña, procurando a maior economía compatible coas necesidades da defensa nacional e mantemento do orde. Na terceira falabase da revisión xeral das recompensas militares, outorgadas nas últimas campañas de Cuba, Puerto Rico e Filipinas pola Xunta designada ó efecto, na que terán representación tódolos Institutos do Exército e da Armada. A cuarta referíase á construcción da Mariña de Guerra pola industria particular nacional, arrendando os arsenais do Estado a unha compañía xenuinamente española.

Non se aceptaron, polo tanto, as propostas compostelás sobre fecho de Academias militares, amortización de prazas de oficiais xerais, reducción do contixente e outras moi concretas. En materia de servicio militar obrigatorio, a Asemblea aínda foi máis rotunda, xa que concluíu que non deberan existir nin redención nin sustitución. Acollía a idea da revisión das recompensas militares e dicía que as construccións navais da mariña de guerra deberían facerse pola industria particular nacional, arrendando os arsenais do Estado ás compañías xenuinamente españolas. 
b) As reformas xudiciais e os intereses de Santiago

Existía unha viva preocupación pola situación da xusticia, altamente politizada, venal e sometida ás oligarquías dominantes, polo menos en certos segmentos da xusticia municipal. Por eso, no seu programa de 13 de novembro de 1898, a Cámara Agraria do Alto Aragón ofrecía un modelo de organización do poder xurisdiccional. Baixo o imperio intelectual de Xoaquín Costa, ofrecía unha descrición institucional da vida política e administrativa, na que a organización xurisdiccional ocupaba unha parte importante. Tribunais que funcionaran na mesma residencia dos litigantes ou a curta distancia, que a sociedade intervira nos xuicios, como único modo de que sexa libre, métodos sinxelos de enxuiciar, tribunais municipais de equidade, tribunal de alzada nas comarcas, tribunal especial de xuíces de cada rexión, intervención voluntaria, non obrigatoria, de avogados e procuradores eran algunhas das súas propostas.

Curiosamente, interesabase a supresión das Audiencias do Criminal, cando Santiago precisamente loitaba por mantela súa, sobre todo polo esforzo da Real Sociedade Económica de Amigos do País de Santiago. A Lei de presupostos de 20 de xuño de 1890 supimeunas, cando desde 1886 se buscaba unha sala do civil tamén. En 1893 houbo un movemento para mantela Audiencia do Criminal, insistindo en 1899 Montero Ríos con unha emenda á lei de presupostos.

A Cámara interesabase pola creación dos Tribunais de Partido, idea formulada por Uxío Montero Ríos na Lei provisoria do Poder Xudicial. En Santiago, a idea foi sempre moi ben recibida, tanto pola Cámara como por outras institucións, incluído concello baixo o mandato de Cleto Troncoso ${ }^{7}$. Tamén propiciaban a supresión de procuradores e relatores, a simplificación de trámites de axuiciamento civil, a reforma da lexislación de quebras. Concretamente, para Galicia, pidiabase a «redención forzosa en Galicia y Asturias de los foros». No apartado cuarto das conclusións, adicaronse capítulos á reorganización da carreira xudicial. Entre as propostas concretas do ramo comercial, querían o restablecemento dos Tribunais de Comercio. O Decreto de 6 de decembro de 1868 estableciu a unidade de foros, suprimindo precisamente os tribunais de Facenda e de Comercio.

\footnotetext{
'Baldomero CORES TRASMONTE: Historia do colexio de avogados de Santiago. Tomo 1. Século XIX. Santiago, 1990, pp. 67-70.
}

"CUADERNOS DE ESTUDIOS GALLEGOS", Tomo XLII, Fascículo 107, Santiago 1995. 
Nas conclusións da Asemblea reclamabase a independencia absoluta do poder xudicial, o ingreso por oposición, a separación efectivas das carreiras fiscal e xudicial, reformas sobre responsablidade de xuíces. Pedía, tamén, a creación da xurisdicción mercantil, unha administración de xusticia rápida e económica, castigando ó litigante insolvente declarado temerario con penas persoais. Asi mesmo, pedían o aumento das contías dos xuicios verbais, a reforma dos penais, con tendencia ó progreso moral dos reclusos. Suavizaron, en definitiva, a proposta compostelá, fixando como potestativo das partes litigantes, en tódolos xuicios, tanto civís como criminais, estar ou non representadas polos procuradores, sen dicir nada sobre os avogados, ós que tamén se referían os cameralistas de Santiago.

\section{c) A reforma da ensinanza}

No apartado das reformas de ensinanza, os cameralistas de Santiago pretendían dotar a cada municipio de un veterinario que, ó mesmo tempo que cumprira os deberes do seu cargo, instruíra ós mozos que quixeran ingresar nas escolas de Veterinaria rexionais. Estes veterinarios, segundo a proposta, poderían constituílo corpo de veterinarios forenses. A proposta non pasou ás conclusións da Asemblea, quizáis por ser demasiado concreta. A Cámara compostelá propoñía a creación de Escolas de Artes e Oficios e de Comercio en número suficiente. No programa da Cámara Agraria do Alto Aragón estaba, asi mesmo, explícitamente formulada esta idea: «Creación de Escolas e artes e oficios, numerosas, con carácter predominantemente práctico». De numerosas pasou a Cámara compostelana a suficientes, que era un concepto máis ambicioso, xa que o número non indicaba que fóran suficientes. Sen embargo, hai que lembrarse do Real Decreto de 9 de abril de 1885, suscrito por Montero Ríos, sendo Ministro de Fomento, polo que se creaban as Cámaras de Comercio, asignándolle a función expresa de fomentar directa ou indirectamente a ensinanza comercial, industrial e marítima. A proposta compostelana tamén inclúe o Comercio.

A ensinanza primaria obrigatoria e gratuita, dándolle máis amplitude e establecemento de premios, foi aceptada pola Asemblea como efectividade do precepto da ensinanza elemental, gratuita e obrigatoria. Inspirada no manifesto de Barbastro, ademais, a Asemblea fixo constálo seu desexo de transformación da instrucción pública xeral, dándolle un carácter positivo, reducindo o número de Universidades e creando escolas de agricultura e de aplicación ás diferentes artes e industrias, e favorecendo a actual carreira de comercio, na que estaban incluídos algúns aspectos da proposta 
compostelana. Tamén fixo constala Asemblea, o restablecemento da disciplina escolar en tódolos seus ordes, alcanzando a evitalos abusos cometidos en materia de libros de texto.

En cambio, destaca a ausencia de conclusións reclamando o abono do soldos dos mestres. O programa de Barbastro incluía: «Pago de sus haberes a los maestros por el Estado». Entrará, por fín, no presuposto do Estado de 1902. A obriga dos concellos pasou ó Estado, que só axudaba con unha subvención. Por Real Decreto de 30 de abril de 1886, Uxío Montero Ríos mandou incluír nos presupostos do Estado os cretos necesarios para o pago dos mestres e escola, normais e profesores de ensino medio, con cargo ó Estado. Pero, a renuncia do ministro paralizou a decisión, ata que en 1901, o Conde de Romanones declarounos funcionarios e nos presupostos de 1902 resolveuse definitivamente a cuestión. Non deixa de ser curiosa, sen embargo, a omisión, tendo en conta que está formulada polo programa da Cámara Agraria do Alto Aragón.

\section{d) As reformas económicas}

O apartado de reformas económicas inclúe seis cláusulas de diferente natureza. Afecta a medidas de fomento, de servicios de ensinanzas agrarias, artes e oficios, construcción de camiños, fomento de pequenas industrias e limitación de circulación fiduciaria. As conclusións da Asemblea, en materia económica, fóron moito máis extensas e estaban incluídas na parte de Fomento. A ensinanza práctica, ademais, foi incluída neste apartado de reformas económicas dos cameralistas compostelás. Creación de obradoiros, granxas modelo, campos de experimentación agrícola e cruzamentos de gando para a experiencia práctica das Escolas de Veterinaria e de Artes e Oficios eran, asi mesmo, outras propostas compostelanas.

A inmediata repoboación e fomento dos montes públicos e restablecemento da antiga garda rural, unha lexislación especial para construir coa rapidez posible camiños veciñais, combinando o traballo forzoso do vecindario co auxilio ou subvención do tesouro rexional ou de cada provincia eran algunhas das propostas da Cámara compostelana. Tamén incluían a petición de lexislación especial para favorecelo desenvolvemento das pequenas industrias agrícolas e gandeiras, por medio de sociedades cooperativas de producción e de creto. Poida que a influencia de Alfredo Brañas, tan preocupado polo establecemento en Galicia das pequenas industrias, sobre todo rurais, quedara nas conclusión dun xeito directo. Como poida que, aínda que en forma máis remota, o eco de Díaz de Rábago, un 
dos primeiros tratadistas do cooperativismo, deixara sentir tamén a súa influencia.

Motivo de especial atención nos debates da Asemblea foi o relativo á limitación fiduciaria do Banco de España, e derrogación do privilexio de emisión ata 2.500 millóns de pesetas. Non se inclinan polo metalismo nin polo bimetalismo, nin os contrapoñen ó diñerio ou a circulación fiduciaria, senón que pretenden reducila a límites aceptables. Non seguían, polo tanto, a ofertade Alfredo Brañas, no seu discurso académico La crísis económica en la época presente y la descentralización regional, de 1893, no que fixo unha crítica da sumisión do Tesouro ó Banco de España e as avantaxes que este recibira coa emisión de $1891^{8}$. Conselleiro de algúns dos cameralistas, polo menos en materia financeira, o eco de Brañas podía sela orixe da proposta compostelana. As conclusións da Asemblea, sen embargo, aínda foron máis detalldas que a proposta dos comerciantes santiagueses.

\section{e) As reformas fiscais}

En relación coa débeda pública incluíronse tres conclusións. Defendíase o pago en pesetas dos intereses de tódalas débedas, xa sexan os tenedores nacionais ou extranxeiros; pidiabase, asi mesmo, a unificación da débeda pública española, mediante a emisión dun gran empréstito, e un sistema de conversións fáciles e de seguros e positivos resultados. Tamén se reclamaba a creación dun imposto xeral sobre a débeda pública.

As conclusións cameralistas pretendían a supresión de varios impostos, algúns moi coñecidos, como o de consumos e de cédulas persoais, e a súa sustitución por un imposto persoal graduado sobre a renda en globo de cada cidadán, e cobrado polo sistema de encabezamentos gremiais forzosos. Se ben o imposto persoal fóra moi criticado cando o instaurara Figuerola, en 1869, pero non tanto pola súa entidade como polas dificultades de facelo efectivo, os cameralistas ofrecían algunhas solucións para melloralo.

A organización fiscal era motivo de interese para os delegados compostelá. Pretendían a abolición do sistema de arrendo para tódolos impostos sobre o capital, a renda e as persoas. En cambio, favorecíase o sistema de arrendo da renda de alfándegas e a necesidade de utilizalos

${ }^{8}$ Alfredo BRAÑAS MENÉNDEZ: La crisis económica en la época presente y la de centralización regional. Santiago, 1992.

"CUADERNOS DE ESTUdIOS GALLEGOS", Tomo XLII, Fascículo 107, Santiago 1995. 
xefes e oficiais da escala de reserva nos destinos civís, como formación do catastro, inspección dos impostos, etc., economizando deste modo o soldo de outros empregados. Completabanse as conclusións coa petición do libre e cultivo do tabaco, coa reforma da lexislación de clases pasivas e a elaboración de normas de contratación pública, establecendo a subhasta pública, e, en definitiva, a codificación das leis de Facenda, simplificándoas ata o ultimo extremo. Máis ou menos, apareceron logo entre as conclusións da Asemblea moitas destas propostas, se ben dentro de Fomento ou de Facenda.

Nas distintas seccións figuran aspectos relacionados coas reformas administrativas e políticas. Sobre todo, existen referencias en relación coa supresión de distintos organismos. Pero, co fín de unilos sistemáticamente, serán obxecto de especial atención, cando se trate, precisamente, dos aspectos políticos e administrativos, que son, certamente, os que máis xustifican a incorporación máis concreta das propostas ós modelos organizativos de Galicia. Sen tal pretensión, as conclusións políticas e administrativas poden ser incluídas entre aqueles modelos de organización política e administrativa de Galicia, que, polo demais, tampouco son tantos desde aquela Constitución para o Estado galaico de 1887, as propostas de Alfredo Brañas, e algunha que outra, ata chegar, naturalmente, ó primeiro e culminar logo o segundo procesos de elaboración e de aprobación dos Estatutos de 1936 e de 1981.

\section{AS PROPOSTAS POLÍTICAS PARA A REFORMA POLÍTICA}

As reformas políticas formuladas pola Cámara de Comercio de Santiago na Asemblea de Cámaras de Comercio de Zaragoza entre o 21 e o 27 de novembro de 1898 extendíanse á reducción de ministerios, á incompatibilidade de cargos de senador e deputado con empregos públicos, á reducción de categorías no corpo diplomático e a reforma da lei electoral con respecto á representación corporativa no Congreso e no Senado. A Cámara de Comercio fixo soamente cinco propostas, destinadas a contelo gasto público e controlala acción política9. Contrasta este lacónico elenco de problemas ca detallada relación de órganos a suprimir que fai a

${ }^{9}$ Baldomero CORES TRASMONTE: As propostas políticas e administrativas da Cámara de Comercio de Santiago en 1898. Revista da Federación Galega de Municipios e Provincias, número 6, outono 1994, PP. 38-45.

"CUADERNOS DE ESTUdIOS GALleGOS", Tomo XLII, Fascículo 107, Santiago 1995. 
Cámara agrícola de Barbastro, como sabemos inspiradora, en certo modo, de aquel alento rexeneracionista que impregnaba as actividades das Cámaras de Comercio, cando a difícil saída do Desastre de 1898. Costa, en realidade, no programa de Barbastro, nun epígrafe titulado Administración central, ofrecía, en cambio, unha supresión radical das direccións xerais que quedasen, reorganizando os ministerios de Facenda, Guerra, Estado e Gobernación en seccións ou negociados autónomos, con facultades propias, directamente responsables dos seus actos ante os tribunais, con fianza para multas e sen superior xerárquico máis que para as reclamacións e recursos. No programa da Asemblea nacional de productores, do 10 de abril de 1899 , repetiráse ó pe da letra este apartado.

A reducción de ministerios era a forma máis socorrida para intentar resolvela cuestión do gasto público. Non se pretendía formular un modelo distinto de Administración central do Estado, fortemente implantada baixo o modelo napoleónico, despois de desplazala organización territorial dos consellos. Era soamente unha medida de racionalización do gasto, evitando duplicidades e intentando establecer unha relación entre o órgano e a función. Os cameralistas compostelanos querían soamente reducilos ministerios, deixando unicamente os de Presidencia e Estado, Defensa Nacional, integrando Guerra e Mariña; Interior, unindo Gobernación e Fomento; Facenda; e Xusticia e Cultos. Todo o referente ás colonias que quedasen, se quedaban algunhas, dicían os cameralistas compostelanos, formarían unha Sección no Ministerio de Estado. Para os cameralistas santiagueses, polo tanto, a organización ministerial quedaba reducida a cinco departamentos. A Asemblea de Zaragoza non seguirá este modelo, xa que preferiu pedila creación dun Ministerio de Agricultura.

Non lle faltaban, ademais do programa de Barbastro, algúns antecedentes e algunha inspiración no modelo reducido de organización do goberno central. Alfredo Brañas, en El Regionalismo, formulaba un modelo de cinco departamentos. En outra proposta, para a Deputación rexional única, organizaba dez secretarías, nas que se incluían a Militar, Facenda, Xusticia, De Relacións Eclesiásticas, Obras Públicas, Instrucción Pública, Industrias, Administración municipal e Beneficencia e Sanidade. A fonte de inspiración dos cameralistas puidera ser, sen embargo, o Curso de Derecho Politico de Vicente Santamaría de Paredes, de 1893, ben coñecido de todos na súa época, na que di que hai en tódolos países un ministro encargado de asuntos exteriores, (Ministro de Estado ou de Negocios Extranxeiros), outro dos militares (Ministro da Guerra), outro dos xudiciais (ministro de Xusticia), e outro da xestión económica do Estado (ministro de Facenda).

"CUADERNOS DE ESTUDIOS GALLEGOS", Tomo XLII, Fascículo 107, Santiago 1995. 
A Asemblea aprobou a seguinte conclusión, baixo o número oito das políticas: «Supresión del Ministerio de Ultramar y creación de uno de Agricultura, Industria y Comercio». En Guerra e Mariña, conclusión quinta, acordaron: «Redención de los Ministros de Guerra y Marina en uno solo». Na sexta dicían: «Incorporación al Ministerio de Agricultura, Industria y Comercio de todo lo concerniente a la marina mercante». No debate, Lucas de la Riva non aceptou de bo grao a proposta que se lle fixo de solicitar un novo ministerio, porque, dicía, o fomento da industria e o florecemento do comercio podían encomendarselle ó Ministerio de Interior.

Cando se fan as propostas, o goberno está presidido por Práxedes Mateo Sagasta. Iniciara a súa actividade o día 18 de maio de 1898 e rematará o 4 de marzo de 1899. Estaba formado polos ministerios da Presidencia, Estado, Fomento, Gobernación, Gracia e Xusticia, Guerra, Facenda e Mariña. O ministerio de Ultramar foi suprimido o 25 de abril de 1899 , encargándose do despacho dos asuntos pendentes o ministerio de Fomento. Creado, nunha primeira etapa, por reais decretos de 30 de setembro de 1851 e de 1854 , confirmouse logo como un ministerio específico por decreto de 20 de maio de 1863.

Máis tradición na organización da Administración central española tiña o Ministerio de Fomento. O no seu segundo goberno, Francisco Silvela, tentanto de aplicar algunhas das propostas de Zaragoza, acordou a supresión do Ministerio de Fomento e a creación, no seu sitio, dos Ministerios de Instrucción Pública e no de longo título de Agricultura, Industria, Comercio e Obras Públicas. Non deixaban de ser curiosas as variacións orgánicas deste ministerio, xa que, creado o ministerio de Fomento por Real decreto de 20 de outubro de 1851, integrando a Secretaría de Estado e do Despacho de Comercio, Instruccións e Obras Públicas, volvía agora a duplicarse en aqueles dous que lle deran orixe, se ben cun nome aínda máis longo. Baixo a presidencia de Montero Ríos, por Real decreto de 6 de outubro de 1905, recuperará a denominación de ministerio de Fomento. Montero Ríos fora, precisamente, titular do ministerio, baixo esa denominación, nun goberno de Sagasta, entre o 27 de novembro de 1885 e o 10 de outubro de 1886.

Outro problema que preocupaba ós cameralistas compostelás era o da incompatibilidade dos cargos públicos. A terceira das propostas dicía: «Incompatibilidad de los cargos de Ministro con los de Consejeros de toda empres a pública y privada». A terceira dicía: «Incompatibilidad de los cargos de Senador y Diputado con toda clase de empleos retribuídos con fondos del Estado, la provincia o el Municipio». A Asemblea aprobou 
unha conclusión na que, dalgún xeito, se resumía o concepto con algunhas variacións ou diferencias: «Incompatibilidad de los cargos de Diputado y Senador electivo en los empleos administrativos y con los de presidente y consejero de sociedades de ferrocarriles, de crédito, monopolios y ortras subvencionadas por el Estado. Los cargos de Senador y Diputado no conferirán categorá administrativa ni habilitarán para el desempeñar destinos públicos».

A Constitución de 1876, a carón de membros por dereito propio e vitalicios, admitía no Senado membros elixidos polas corporacións do Estado e maiores contribuíntes na forma que a lei determinase. A lei de 8 de febreiro de 1877 reduciu o dereito a ser senadores ás corporacións eclesiásticas, académicas, ás universidades e ás Sociedades Económicas de Amigos do País. Outras entidades, como as cámaras agrarias ou as de comercio, non tiñan dereito a elixir senadores. Para Cámara dos deputados, sen embargo, non chegou a implantarse o sistema. A lei electoral de 26 de xuño de 1890 , no seu artigo 22 , creou, para o Congreso dos deputados, os colexios especiais, integrados polas Universidades literarias, as Sociedades económicas e agrícolas organizadas oficialmente. No artigo 26 especifícase algo máis o concepto de sociedades económicas e agrícolas, mencionando expresamente ás Cámaras de comercio, industriais ou agrícolas. Os colexios especiais, sen embargo, que funcionaban no Senado para as corporacións devanditas, non chegaron a ser implantadas na realidades política española ${ }^{10}$.

Por eso, as Cámaras, a de Santiago concretamente, coidaban necesaria a implantación do colexio electoral corporativo, ou, quizais, con mais precisión, o colexio electoral especial, sen negar, polo menos explícitamente, a súa coexistencia co sufraxio universal inorgánico. Pretendían a ampliación á representación de clases e concedendo ás Cámaras de Comercio, Industriais e Agrícolas a representación axeitada no Congreso e no Senado. As conclusións da Asemblea non se separaban moito, xa que se refería ó réxime electoral, sinceiramente practicado, sustituíndose pola representación por clases para os concellos, provincias e Cortes. Como primeira conclusión, a Asemblea aprobou a seguinte: «Régimen electoral, sinceramente practicado, para los organismos provinciales y municipales,

\footnotetext{
${ }^{10}$ Baldomero CORES TRASMONTE: La representación corporativa y el papel de la Universidad compostelana en el senado español. «Revista de las Cortes Generales». Madrid, segundo cuatrimestre, 1991, pp. 79-101.
}

"CUADERNOS DE ESTUdIOS GALLEGOS", Tomo XLIl, Fascículo 107, Santiago 1995. 
sustituyendo al actual sistema la representación por clases, incluso la obrera. El mismo procedimiento se practicará en la elección de diptuados a Cortes».

\section{AS REFORMAS ADMINISTRATIVAS}

As reformas administrativas extendíanse á supresión das provincias administrativas españolas, dos seus gobernos civís e deputacións provinciais. Tamén se referían a reducción do número de concellos, con especial excepción para Galicia. Tamén eran partidarios de que se aprobase unha lei de funcionarios. Os cameralistas compostelanos coidaban que a organización provincial precisaba dunha nova estructura, axeitada ás necesidades rexionais, e contraria, polo tanto, á organización provincial existente. Entre as reformas administrativas destacan as referentes á supresión de tódalas provincias administrativas españolas, dos seus Gobernos civís e as Deputacións provinciais. En sustitución do sistema provincial establecido formulabase un modelo de provincias rexionais, cada unha con unha Deputación única" ${ }^{11}$.

A segunda dicía que: «En cada provincia regional habrá una Diputación única». ¿Procedía de Alfredo Brañas esta terminoloxía da Deputación única? Nun artigo publicado o 10 de outubro de 1898, o líder rexionalista falaba dunha Deputación do Reino, única e suprema. O adxectivo de únicidade non existía cando a Deputación provincial de Galicia, entre 1812 e 1823. A adxectivación da Deputación provincial como única é, simplemente, unha forma semántica de contraste e de oposición ó sistema cuatripartito das provincias establecido en Galicia desde 1821. Ten, incluso, algunha connotación ideolóxica, como oposición ó sistema establecido polo real decreto de 30 de novembro de 1833 , como unha implícita medida de sustitución das provincias por unha soa provincia. Foi un adxectivo que indicaba, implícitamente, que se pretendía a supresión das catro provincia e a sustitución por unha soa provincia. Algunha das propostas formuladas polos delegados da Cámara de Comercio de Santiago viñan sendo formu-

\footnotetext{
${ }^{11}$ Baldomero CORES TRASMONTE: Perfil de Galicia. A demarcación perimental e a organización política. Revista da Federación Galega de Municipios e Provincias. Número 4, 1994, pp. 31-39; Pablo GONZÁLEZ MARIÑAS: Las diputaciones provinciales en Galicia: del Antiguo Régimen al constitucionalismo. Deputación provincial da Coruña. A Coruña, 1978.
}

"CUADERNOS DE ESTUdiOS GALLEGOS", Tomo XLII, Fascículo 107, Santiago 1995. 
ladas tamén por Alfredo Brañas desde facía algún tempo. O concepto de Deputación rexional única, por exemplo, era unha idea que mantiña desde facía tempo. Exa nas proximidades da Asemblea de Zaragoza, o día 10 de outubro de 1898, falaba dunha Deputación única rexional, como unha Deputación do Reino, única e suprema.

A alteración do sistema provincial, establecido polo real decreto de 30 de novembro de 1833, fóra obxecto en varias ocasións de iniciativas lexislativas. No Real Decreto de 29 de setembro de 1847, organizando a gobernación civil do Reino, Escosura dividía o territorio da península en once gobernos xerais, que non variaba moito con respecto á proposta dos cameralistas compostelanos e, ó mesmo tempo, do mapa autonómico derivado do Estado de Autonomías. Sexismundo Moret, a súa vez, persentara un proxecto de lei provincial, o 5 de xaneiro de 1884, no que se facía unha demarcación do territorio penínsular sobre a base de dezaseis demarcacións provinciais. No proxecto de Sánchez de Toca eran trece ás demarcacións provinciais. En todas elas, por suposto, se respeta a demarcación provincial, como tales provincias, pois son, en realidade, reformas da lexislación local, polo que non teñen filiación algunha próxima a unha organización rexionalista.

A división territorial proposta polos cameralistas santiagueses cifrabase nas 17 provincias rexionais seguintes:

Galicia.

Asturias

León (León, Palencia, Zamora e Salamanca).

Castela a Vella.

Castela a Nova.

A Montaña (Santander).

Vascongadas.

Navarra.

Aragón.

Cataluña.

Valencia.

Murcia.

Andalucía do Norde (Córdoba, Xaén, Granada e Almería).

Andalucía Baixa.

Extremadura.

Baleares.

Canarias.

"CUADERNOS DE ESTUdIOS GALlEGOS", Tomo XLII, Fascículo 107, Santiago 1995. 
Galicia aparece en tódalas divisións coñecidas integrada polas catro provincias. As posibilidades da quinta provincia, do Bierzo, xa non eran discutibles. No de Escosura, Valencia e Murcia formaban unha unidade, e Granada e Sevilla dividían Andalucía. Tamén aparecía Burgos coma unha rexión, na que ademais de Burgos, Logroño, e Soria aparecía Santander, o que se chama a Montaña. Asturias quedaba integrada en Castela a Vella. En cambio, Asturias, no de Moret, incluía León, Murcia incluía tamén a Alicante, Vascongadas á Navarra, Valladolid formaba provincia e Madrid dirixía a Guadalaxara e Toledo.

Estas provincias terán ó seu fronte Gobernadores, xefes da administración rexional. Non se adxectiva, neste caso, o cargo do gobernador. Non en tódolos modelos se adxectivaba a denominación do cargo. Máis ben se facía para indicar que coexistía con outros gobernadores. No modelo de Sánchez de Toca, por exemplo, institucionalízase o rol de Gobernador rexional, pero subsisten os gobernadores provinciais, dos que aquel sería o xefe inmediato. Asi mesmo, a subsistencia ou supresión das deputacións provinciais dáballe un sentido rexionalista ou non a aqueles modelos que pretendían unificala organización política e administrativa desde unha perspectiva rexional.

A proposta de supresión das deputacións foi un dos asuntos máis polémicos da Asemblea de Zarazoga. Entre os propoñentes da supresión estaban os representantes das Cámaras galegas e os de Oviedo, Santander e Valencia. No debate, a Comisión non aceptou a supresión das deputacións provinciais, que propoñían unidos os representantes galegos, os de Asturias e outros. Deixaba aberta a posibilidade de formar unidades mais grandes. A Asemblea foi máis aló, propoñendo a posibilidade de concertos económicos, revisables, entre as provincias que o soliciten e o Estado, polos quedan aquelas autorizadas para repartir, investigar e recadar as contribucións e impostos. En contra dos votos dos representantes santiagueses e de Xosé López Trigo, Nicandro Fariña e Ulpiano Galindo, os delegados coruñeses, tivo duras palabras $\mathrm{La} \mathrm{Voz}$ de Galicia, nun editorial titulado «La Asamblea de Zaragoza y nuestros representantes». O xornal preguntaba: «¿Como creer que los señores Luego y La Riva hayan votado conscientemente por la supresión de una Diputación que invierte en Santiago la mitad de sus presupuesto, repartiéndolo en menesteres tan meritorios como son el sustento de su gran Hospital, el del Hospital de leprosos, el de la Casa de expósitos, las subvenciones a la Sociedad económica y a la escuela de sordo-mudos y ciegos, la cooperación a la magna obra de Payá, o séase el incomparable manicomio de Conjo, y otras subvenciones igual- 
mente saludables para la economía del país? ¿Como imaginar que pueden los Sres. López Trigo, Fariña, Galindo vetar deliberadamente con bola negra sobre el concepto de una Diputación a la cual se debe que fuesen ahora elevadas a superiores las Escuelas normal de maestras y la de Comercio de La Coruña, sin que por ese nuevo esfuerzo se le ocurriese temer que van a quedar sin cobrar las amas de cria, como sucede en Málaga, los profesores de las Escuelas de Bellas Artes, como acontece en Murcia, y los empleados y proveedores de la cárcel, como ocurre en Granada?».

Nas conclusións, a Asemblea, en cambio, formulou o principio claramente: «Se considera necesario y urgente conceder a las Provincias y los Municipios amplia descentralización económica y administrativa», di na segunda conclusión. O 20 de outubro de 1898 celebrárase o Congreso Administrativo en Madrid, no que se defendía a descentralización administrativa. Tamén foi pedida por unha comisión de Barcelona á Raíña. A Asemblea de Zaragoza desbotouna. Defendíase como unha defensa contra o rexionalismo, porque estes aíllas ás rexións, pero son tendencias distintas, aínda que moitos congresistas as confundían.

A provincia rexional dividiríase en concellos ou municipios superiores, cantas fóran as súas antigas cidades, comarcas ou outras divisións naturais e históricas da rexión. Habería que reducilos concellos actuais, conservándose soamente nos pobos superiores ós 3.000 habitantes, de xeito que en Galicia, que cita como pasaríase, pasaraíabase de 324 a oitenta, número colosal que fai complicadísima a maquinaria administrativa, e é a causa do funesto caciquismo que arruína e empobrece a nosa desditada clase labradora. Nos pobos onde non houbera concellos, podería haber correxidores ou alcaldes pedáneos, subordinados ó municipio correspondente. O Congreso, nas súas conclusións, rebaixou a mil habitantes, «salvo en las provincias de Galicia donde, por sus condiciones especiales, se exige un régimen excepcional». Tamén neste aspecto pode ollarse o impacto de Alfredo Brañas, pois viña dicindo que os concellos, en número de máis de 300 , debían reducirse a uns oitenta e tantos, cousa que se refreixa nidiamente na proposta da Cámara de Comercio. Precisamente, o día 21 de novembro saíu un artigo en El Correo Español, no que concretaba que dos 324 concellos galegos conservaríanse 85 , distribuídos entre dez cidades.

A organización dos servidores da Administración pública era outro dos asuntos que preocupaba ós cameralistas de Santiago e ás Cámaras de Comercio de España. Pedían a publicación inmediata dunha lei de empregados sobre a base da oposición para o ingreso, inamovibilidade, escalafón fechado para os ascensos, declaración de inamobilidade para os que levaran 
máis de cinco anos consecutivos ou xunten oito en diferentes épocas, reducción de empregos ós estrictamente necesarios para o servicio público e sinalamento de horas de oficina. Na conclusión novena, a Asemblea fixo constar esta preocupación coas seguintes palabras: «Creación de la carrera de Administración civil, en los ramos en que no lo está todavía, estableciendo el ingreso por oposición con propuesta unipersonal, la inamovilidad y responsabilidad de los empleados públicos, simplificándose el expediente. Todos los cargos en el servicio del Estado, incluso los de Directores generales, tendrán carácter técnico, proveyéndose en las respectivas carreras, reservando solo, como nombramientos políticos, exclusivamente los de Ministros de la Corona y Subsecretarios»».

II

ENTRE ALFREDO BRAÑAS E A LONGA SOMBRA DE MONTERO RIOS, XOAQUÍN COSTA, E UN BANQUETE APAIXOADO

\section{AS IDEOLOXÍAS SOTERRADAS E AS CONCLUSIÓNS DA CÁMARA DE COMERCIO}

A ideoloxía soterrada nas conclusións obedecía a un principio rexeneracionista, de austeridade, contención do gasto, reducción do servicio público. Tamén moralidade, creación dunha conciencia pública. No fondo, sen embargo, aínda que pretendían ser neutrais, por actuar só coma clases productoras, dificilmente podían librarse das ideoloxías locais. En Santiago dominaban, polo menos en certas clases medias e medias altas tanto a esperanza de Alfredo Brañas como a forza política directa de Uxío Montero Ríos, máis aló da intensidade de ideoloxías partidistas. Da mistura ideolóxica, por exemplo, non se libraba o mesmo Alfredo Brañas, con sentido ambiguo ante a figura dominante de Montero Ríos.

¿Había unha influencia directa, inmediata, quizáis unha autoría ou unha colaboración de Alfredo Brañas na elaboración do modelo organizativo da Cámara de Comercio compostelá?. Alfredo Brañas e Salvador Cabeza de León eran presidentes honorarios da Cámara de Comercio. Alfredo Brañas, pola súa especialización facendística, era consultado decote por Lucas de la Riva, o presidente da Cámara. En proba de agradecemento, por exemplo, na sesión do 18 de abril de 1898, acordou a Cámara sumarse á Comisión 
presidida por Brañas sobre o monumento a Rosalía de Castro. Na sesión da corporación, do 4 de abril de 1898, acordaron asistir á procesión da Virxe das Doores, que presidía Brañas aportando trinta libras de cera ${ }^{12}$. Tanto Cabeza como Brañas, ademais, estiveron no banquete celebrado en homenaxe ós representantes da Cámara na Asemblea de Zaragoza, Lucas la Riva e Luengo.

En homenaxe a Lucas de la Riva e a Xosé Luengo, os comisionados de Zaragoza, recibidos en Santiago con gran agasallo, celebrouse, no Círculo Mercantil e Industrial de Santiago, un banquete moi sonado, o día 4 de decembro de 1898. Os organizadores cuidaron os detalles con gran esmero. No testeiro líanse as seguintes inscricións: «Zaragoza», «Cartagena», «Patria», «Regeneración». Fronte da cabeza da mesa estas outras: «Paraíso» (presidente da Cámara de Zaragoza e gran iniciador, con Costa, do movemento rexeneracionista), «Norte» (presidente da Cámara de Cartaxena), «Pérez Lube» (iniciador da Asemblea). Entre escudos e outros adornos, ós lados, había estas outras: «Moralidad», «Justicia», «Trabajo», «Valor cívico», «Economía», «Orden», que definían todas elas as intencións dos asembleístas. A mesa dos oitenta comensais tiña a forma de «C», inicial de Comercio.

Despois de intervencións dos oferentes do banquete e dos agasallados,

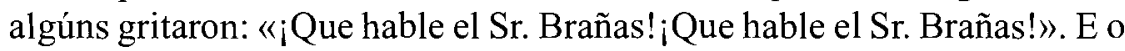
señor Brañas, que non necesitaba de demasiadas excitacións para falar, alzou a súa voz en ton pesimista, o que contrastaba con aquel entusiasmo que irradiaban os comerciantes. Dixo que o dominanban os sentimentos de amistade e de patriotismo. O primeiro, polo afecto que sentía polos homenaxeados. O patriotismo, en cambio, deulle un ton pesimista: «¿Conseguirán su objeto las Cámaras españolas? ¡Ay, amigos mios! No está en mi carácter amargar triunfos ni enfriar ilusiones, pero me habéis de permitir que os diga: la voz del comercio es la voz de España, pero el Mensaje de Zaragoza pasando de largo por las manos de una Soberana que no reina sola, que no puede juzgar ni castigar, caerá en manos de los mismos caciques, de los mismos hombres que labraron nuestra ruína y hundieron a España en el abismo de sus actuales miserias». E pon a seguintes testemuña:

${ }^{12} \mathrm{Na}$ Gaceta de Galicia e no Eco de Santiago ámplia información sobre a materia. Na sesión do 3-XII-98, da Xunta directiva da Cámara de Comercio de Santiago, Libro de Actas, pp. 73-4.

"CUADERnOS DE ESTUdIOS GALLEGOS", Tomo XLII, Fascículo 107, Santiago 1995. 
«Con menos solemnidad que vosotros, en unión de dos vascos-navarros y tres catalanes tuve la honra de presentar a la Reina Regente un Mensaje en que como vosotros le pedimos la libertad del sufragio y la reforma de la administración pública. Ofreciónos la Soberana recomendar nuestro Mensaje a los Ministros, y aunque muy agradecidos a la amabilidad de la augusta Señora salímos de la regia estancia con las ilusiones perdidas y las esperanzas muertas. El tiempo vino a darnos la razón». Brañas decatouse do ton amargo e aprestouse a aclaralo seguinte: «Me diréis que estoy demasiado pesimista, que he perdido la fe en todo. No es exacto. Puede haber remedio para España. ¿Donde está? No sabría decíroslo, no intento descubrirlo; no quiero saberlo. Dios es el que tiene el secreto y la llave de la suerte de los pueblos».

Pola súa banda, o longo brazo, sutil brazo, a corda ideolóxica, persoal e directa de Uxío Montero Ríos chegaba ata a Cámara de Comercio, como ás demais institucións e corporacións compostelanas. Cando estaban os liberais no poder, Montero tiña un poder directo para axudar a Santiago, pero, aínda en momentos adversos inxeniaba mil trucos para colaborar coa súa cidade nadal. Cando se celebra a Asemblea de Zaragoza formaba goberno Sagasta. Sexismundo Moret, rival implacable de Montero, non estaba no goberno, pero tivo ocasión de ter algunha intervención na Asemblea, unhas veces directa e outras veces indirectamente, por ser, precisamente, deputado por Zaragoza.

A Cámara acudía a Montero Ríos cando tiña algún problema, e a lista de problemas non deixar de ser curiosa, en moitos casos. Foi fundador das Cámaras, por Real Decreto do 9 de abril de 1886, en aduanas de primeira, como Coruña, Vilagarcía e Vigo, pero tamén naquelas cidades que pola súa importancia puidera designalo Ministerio, mencionándose a de Santiago de Compostela. A Cámara de Santiago estivo sempre moi recoñecida a Montero Ríos. A Cámara de Santiago nomeouno presidente honorario o 8 de marzo de 1889. Na Memoria lída na Xunta Xeral o día 10 de abril de 1890, sendo Manuel Valenciano presidente e secretario Xosé Harguindey, faise historia de coma naciu: «Cupo la honra a un esclarecido hijo de esta ciudad dar forma práctica a la deseada asociación, publicando el memorable Decreto de 9 de abril de 1886, con la razonada exposición que le precede; documento importante...».

$\mathrm{Na}$ Memoria lída o 13 de xaneiro de 1891 faise constar un voto de gracias «por el interés que ha demostrado y los pasos que ha dado hasta conseguir fuesen atendidas las justas pretensiones que esta Directiva sostenía sobre el particular y que fueron satisfactoriamente cumplidas», refe- 
rentes á conquerila rebaixa na base contributiva da matrícula industrial, firmando Lucas de la Riva, como presidente, e Manuel Casas Chico como secretario. Na memoria do 17 de xaneiro de 1897, con motivo da loita contra o monopolio do sal, Lucas de la Riva e Santiago Martínez constituron un movemento, trunfante pola axuda que lles prestoou Montero. Para agradecérllelo esforzo, con Ventura Villar, cumplimentaron ó líder compostelán en Lourizán. O 26 de xaneiro dese ano, dirixironse a Montero Ríos sobre o trazado da estrada de Carril a Pontevedra. Noutras ocasións estarán sempre a pedirlle cousas para Santiago, como, por exemplo, o 16 de marzo de 1903 con respecto ós horarios dos trens, que prexudicaban moito a Galicia.

Non deixa de ser curiosa, por decir chocante, a evocación de Montero Ríos nunha aspiración rexeneracionista. Recoñecendo os seus méritos e a magntitude da súa figura pública e profesional, Xoaquín Costa, compañeiro del na fundación da Institución Libre de Ensinanza, utilizouno como a encarnación esencial da decadencia pátria, como se dicía ó que outros chamaban a moral da derrota. No discurso de 1906, pronunciado en Zaragoza, baixo o título de Las víctimas de la República, resumiu a súa longa e teimuda crítica coas seguintes palabras: «El ha sido el prototipo de esa escogida falange de políticos que han mirado a la patria con el mismo entrañable, tierno y desinteresado amor con que la labradora quiere y agasaja a su lechón».

\section{RAFAEL GASSET, DE CRONISTA DA ASEMBLEA Á EX- PRESIÓN DO REXENERACIONISMO POLÍTICO}

En calidade de corresponsal de El Imparcial, cabe destacala presencia de Rafael Gasset na Asemblea de Zaragoza, tanto porque a súa carreira política terá en Galicia gran asento, como polos desexos que tivo, cando logo ocupou cargos gubernamentais, para levar a cabo algunhas das propostas da Cámara compostelana e das conclusións de Asemblea de Zaragoza. Cando rematou a Asemblea, Gasset dixo: «La Asamblea ha puesto fin a sus patrióticas labores; ha dado el ultimo paso celebrando la sesión de clausura. Nosotros, sin embargo, entendemos que ahora da el primer paso, que ahora comienza sus beneficiosas tareas». Dicía Gasset: «Zaragoza representa hoy a España para este ideal de regeneración y de esperanza que muchos concebimos». Gasset fai unha avaliación ó dicir que «se trata de marcar rumbos y de señalar orientaciones, sin que preten-

"CUADERNOS DE ESTUdiOS GALLEGOS", Tomo XLII, Fascículo 107, Santiago 1995. 
dan los representantes de las Cámaras que se han impuesto tan difícil y patriótica tarea erigirse en Convención ni eclipsar los timbres preclaros e inmortales de las Cortes gaditanas» ${ }^{13}$.

Gasset estimou como un feito moi de alabar que non se amosaran ambicións por cargos políticos, pero él, en non moito tempo, será un dos aventaxados na gobernación rexeneracionista iniciada ou proclamada por Francisco Silvela. Silvela quería siñificados independentes, con zoas de opinion mais extensas que as que interviron en asuntos publicos, como defendía na súa famosa carta do 9 de abril de 1900, utilizando como base o programa da Unión Nacional, e encargou a Gasset, precisamente, do ministerio de Agricultura, de recente creación, nun goberno iniciado o 18 de abril e rematado o 25 de outubro de 1900 , co fin de desenvolver un programa rexeneracionista, mediante reformas xerais.

O programa rexeneracionista de Xoaquín Costa tivo eco nos programas políticos de Francisco Silvela e de Raimundo Fernández Villaverde. Para levar a cabo o programa, tanto un como outro contou con Rafael Gasset e Chinchilla, co fin de transformar en gacetable os seus postulados e converter en políticas públicas o que se chamou a política hidráulica e o intento de modernización da agricultura e das obras públicas. Despois dunha primeira etapa como independente no goberno formado por Francisco Silvela, pasou a un goberno tamén rexeneracionista inspirado na política fiscal, formulado por Raimundo Fernández Villaverde, para integrarse logo e xa dun modo definitivo en gobernos formados polo partido liberal.

Despois desa etapa rexeneracionista, Gasset formou parte de gobernos formados por Segismundo Moret, Xosé Canalejas, o Conde de Romanones e Manuel García Prieto. Coa morte de Sagasta, o día 5 de xaneiro de 1903, as loitas entre familias liberais foi constante, pero Rafael Gasset puido formar parte de distintos gobernos, máis preocupado pola política rexeneracionista, por facer realidade o programa de Xoaquín Costa, que polas loitas domésticas no seo do partido. En algún momento, sen embar-

\footnotetext{
${ }^{13}$ Sobre Rafael Gasset Chinchilla, así como sobre a súa saga, non hai moito escrito en Galicia. Agora soamente damos un apunte sobre a súa traducción do costismo e do rexeneracionismo en actividade gubernamental e en políticas públicas. Podería completarse, por exemplo, coa súa actividade como deputado por distintos distritos galegos. Melchor FERNÁNDEZ ALMAGRO: Historia politica de la España contemporánea (1897-1902). Alianza Editorial. Tomo 3. Madrid, 1970; Historia del reinado de D. Alfonso Xlll (1). Biblioteca de la Historia de España. Madrid, 1986.
}

"CuAdernos De eStudios GALlegoS", Tomo XLiI, Fascículo 107, Santiago 1995. 
go, non puido librarse de tales loitas, como cando, unha vez morto Moret, o intento de ser presidente do Congreso dos deputados veuse frustrado pola oposición de Barroso.

O 18 de abril de 1900 entrou como independente nun Goberno formado por Francisco Silvela, no que tamén entraba como ministro de Facenda entraba Raimundo Fernández Villaverde. A intención rexeneracionista de Silvela, tentando de levar á práctica o programa da Unión Nacional, o programa de Costa, en definitiva, era unha gran tentación, unha tentación ante a que tiña que caer necesariamente, por enriba de calquera definición ideolóxica. O ministerio parecía feito a súa medida, xa que por mor do Real Decreto de 18 de abril de 1900 suprimiuse o Ministerio de Fomento e crearonse, no seu sitio, os Ministerios de Instrucción Pública e Belas Artes, e o de Agricultura, Industria, Comercio e Obras Públicas. Ó fronte deste polifacético Ministerio puxo Silvela a Rafael Gasset, deputado por Noia desde 1893, como antes o fóra pola Estrada. Era director de $\mathrm{El} \mathrm{Im}$ parcial, xornal de grande influencia na corte, de xeito que, ademais de incorporar independentes ó seu Goberno, indirectamente atraía cara o seu programa a unha boa parte da opinión pública.

Non tardou Gasset en dar idea do seu esforzo e do seu intento de atender sobre todo as cuestións económicas e o desenvolvemento hidráulico, agrario e económico en xeral. Por Real decreto de 11 de maio de 1900 reorganizou o servicio hidrolóxico e orientou a política hidráulica. $\mathrm{O} 28 \mathrm{de}$ xuño creou os campos de experimentación e demostración, establecendo un en Pontevedra. Na exposición de motivos hai xa todo un tratado de extensión agraria: "En todos los países donde la agricultura aparece bien dirigida, han sido los campos de experiencia y demostración medio eficacícimo para destruir errores inveterados de aquellos labriegos que resistían las novedades de la ciencia agronómica sin otras razones que las aducidas por equivocada tradición". Remataba: "Para vencer determinadas rutinas, es preciso, es por todo extremo necesario, disponer del hecho real, positivo, tangible, del campo de experiencias. Frente a la demostración práctica no vive el error".

En 1902 desenvolviu o plan de recursos hidráulicos, que foi coñecido como o plan Gasset, consistente en crear setenta mil kilómetros de camiños veciñais. O 27 de novembro de 1903 asinou o Regulamento xeral para a organización e réxime das Xuntas de Obras de canles e de rego e pantanos. Gasset quería facer gacetable a politica hidraulica.

Despois de formar parte do goberno de Silvela, o 20 de xullo de 1903 entrou no goberno de Raimindo Fernández Villaverde, chamado o goberno 
dos "gallegos", porque nel figuraban en Mariña, Cobián Roffignac; en Instrucción Gabino Bugallal Araujo, e en Facenda Augusto González Besada. Gasset entrou coa idea de continualo programa iniciado e insistía no seu plan hidráulico, que era algo máis que o tratamento das augas, xa que insistía na necesidade de desenvolvelo programa de construcción dos setenta mil kilómetros cuadrados.

Villaverde morreu o 15 de xullo de 1905. O 27 de xuño dirixiu un Manifesto ós seus conspicuos, pero xa non puido coñecelo alcance nin os efectos que podía ter sobre a opinión pública. Os villaverdistas, entre os que figuraba Gasset, publicaron un Manifesto o 23 de xullo, insistindo na necesidade de desenvolvela politica hidraulica, a politica agraria e a institucionalización dos sindicatos agrarios, materias que Fernández Villaverde esperaba acometer. A morte de Villaverde significou para Gasset un cambio fundamental na súa adscrición partidista. O programa tecnocrático de fomento non se cambiou, en todolos ministerios en que estivo, pero ofrecíaselle agora a posibilidade de desenvolvelo no seo do partido liberal, máis en consonancia cos seus principios. Mentras outros villaverdistas se orientaron cara a revolución desde arriba de Maura, Gasset preferiu inclinarse cara o partido liberal, do que xa non separará durante a súa vida política.

Da man de Segismundo Moret, sobre todo, Rafael Gasset atopará no partido liberal as canles precisas para facer do costismo, do rexeneracionismo, un conxunto de políticas públicas desde o ministerio de Fomento. Gasset terá que esperar, pois, a que Segismundo Moret forme goberno o 1 de decembro de 1905, para volver a dirixilo ministerio de Fomento, departamento do que agora estaba separado de instrucción pública. En maio ordenou as obras de Aranda de Duero. O 10 de maio sometou ás deputacions provinciais un plan de 50.000 kilómetros de camiños veciñais. Cesou como ministro 6 de xullo de 1906. Despois dun goberno de López Domínguez, o 30 de novembro de 1906 volviu a Fomento, de novo con Moret na presidencia, pero non estivo máis que ata 04 de decembro de ese ano.

Por lei de 28 de xaneiro de 1906 regulouse a constitución e os beneficios tributarios de que poden gozalos sindicatos agrícolas. A Lei de sindicatos agrícolas de Gasset, do 23 de xaneiro de 1906, foi gabada polas Asembleas agrarias de Monforte. Amando Castroviejo dicía dela que, os efectos desta lei, perfectamente inspirada e aplaudida sen reservas no se fixeron esperar e axiña comenzaron a xordir sindicatos ou a transformarse en tales amparándose nos seus precepto as asociacións agrícolas constituídas antes ó abeiro da lei de asociacións. Culpouse a Osma, como ministro da 
Facenda, dun regulamento restrictivo, pero os tiros alcanzaron tamén a Besada, como titular do ministerio de Fomento. Dicta nese momento o regulamento do cultivo do algodón, de 28 de xaneiro de 1906 e o Real decreto de 23 de febreiro de 1906 o regulamento para a aplicación da lei de comunidades de labradores de 8 de xullo de 1898. Nun novo goberno de Segismundo Moret, volverá a ser Ministro de Fomento, desde 21 de outubro de 1909 ata o 9 de febreiro de 1910.

Xosé Canalejas non contou con Gasset no seu primeiro goberno, que vai entre o 9 de febreiro de 1910 e o 2 de xaneiro de 1911. Nunha reorganización gubernamental, producida o 2 de xaneiro, entrará como ministro de Fomento, continuando logo na reorganización do 3 de abril de 1911, pero presentou a demisión o día 12 de marzo de 1912. A súa saída do goberno estaba relacionada coa retirada do Congreso do seu plan de estradas, que quixo explicar que era por erros de copia. Por lei de 7 de xullo de 1911, formula o plan para a construcción de obras hidráulicas con destino a rego e de obras de defensa contra as correntes das augas e por lei de 29 de xuño de 1911 aprobouse o plan de reconstrucción agronómica, dicindo no artigo primeiro que o Goberno redactará un plan de reconstitución agronómica a base de creación de centros agrícolas de carácter experimental naqueles puntos onde non exista outra clase de estaglecementos análogos e utilizando os laboratorios agrícolas provinciais. A esa etapa corresponde a ordenación dos regos no Alto Aragón en 1912.

Inicialmente non entrou no goberno formado polo Conde de Romanones o día 31 de decembro de 1912, sendo nomeado para o cargo de ministro de Fomento Miguel Villanueva. Pero, o 24 de maio de 1913, Gasset ocupará de novo a dirección do ministerio, ata que o goberno foi sustituído o 27 de outubro por un goberno conservador formado por Eduardo Dato. No consello de ministros do 28 de xuño de 1913, déuselle carta aberta para desenvolvela política hidráulica, prometéndose a colaboración de todo o gabinete. Co Conde de Romanones volverá a ocupalo sillón ministerial, nun goberno formado o 30 de abril de 1916, que rematará as súas funcións o 19 de abril de 1917. Non volverá a ser ministro ata o 7 de decembro de 1922, con Manuel García Prieto na presidencia. Será sustituído o 3 de setembro de 1923 por Manuel Portela Valladares.

Como decimos, Gasset quixo facer gacetables os principios elaborados por Xoaquín Costa, aplicando á realidade un modelo rexeneracionista das políticas públicas. A xestión ministerial de Rafael Gasset distingueuse pola contumacia na defensa do programa rexeneracionista de fomento de xeito que o programa tecnocrático de fomento non se cambiou, en todolos minis-

"CUADERNOS DE ESTUDIOS GALLEGOS", Tomo XLII, Fascículo 107, Santiago 1995. 
terios en que estivo. A politica hidraulica era para el a base do desenvolvemento, foran cales foran as familias dominantes no seo do poder gubernamental .

O curriculum político de Rafael Gasset desborda con moito a súa actividade ministerial, pero abondará agora con dar este marco do seu significado e de como implantou na realidade lexislativa o principio esencial do costismo e dos principios rexeneracionistas. Fillo de Eduardo, nado en Pontevedra, hirmán de outro Eduardo e de Ramón, todos eles membros activos do partido liberal, despois dunha primeira experiencia como deputado por Manzanillo, Cuba, foi deputado pola Estrada e, sobre todo, por Noia. As súas loitas electorais e presencias en Galicia con fíns políticos permiten reconstruír unha parte importante da historia política galega, á que estivo sempre tan vencellado como parte de un clan familiar altamente influínte en algúns distritos do país. Podería resumirse, coa urxencia que estas liñas impoñen, a súa situación en Galicia con aquel homenaxe que se lle rendiu en Padrón o día 20 de setembro de 1919, con motivo da súa estancia de días na Torre Xunqueira, propiedade do seu hirmán Eduardo.

No banquete, o deputado C. Antonio Rodríguez dixo que oíndo a Gasset víase nel ó sucesor espiritual de Costa, xa que é continuador e sustentador daquela política que o gran pensador encerraba neste lema: pan e despensa. Rodríguez precisou que se debía a Gasset a idea da entrada de España na Liga de Nacións, xa que presentou unha proposición no Congreso. Tamén indica que foi un dos primeiros que defendiu a idea da representación proporcional para a súa incorporación á lexislación electoral. Gasset corrobou as palabras de Rodríguez, destacando que España fóra o único país neutral na Liga de Nacións, e que tal cousa significou un trunfo seu. "Los caminos vecinales fueron mi preocupación constante y hoy hay ya catorce mil kilómetros que prestan grandes servicios, como tuve ocasión de ver estos días en pueblos de la costa que visité". Para engadir logo: "Eso es lo que he hecho yo mientras otros llenan páginas y más páginas del "Diario de Sesiones" con discursos estériles".

Sobre os principios liberais dixo: "Solo en los principios liberales hay que confiar, y sino ved como países como Alemania y Austria han perecido, mientras los Estados Unidos en que impera la verdadera libertad siguen cada vez más florecientes". Neste mesmo senso, engadiu: "No hay contradicción entre libertad y orden; antes al contrario, la libertad es requisito previo del orden, y sí para conservarla es preciso andar a tiros, yo siendo consejero de la Coruna acosejaría que se disparasen".

"CUADERnOS DE ESTUdios GALlEGOS", Tomo XLiI, Fascículo 107, Santiago 1995. 
Como Augusto González Besada, Gasset será outro branco na atención do partido adversario turnante e, sobre todo, na opinión dos irmandiños. Desde A Nosa Terra tanto un como o outro, cando non El Imparcial, o xornal de Gasset, serán atacados duramente polos irmandiños. O 30 de setembro de 1918, baixo o título de $O$ Rexionalismo besadista, o xornal irmandiño comentou a Real orde pola que se dipoñía que se despachasen con franquicia de dereitos de arancel as carnes conxeladas que se importaran do extranxeiro. A Nosa Terra di que ó pe da dita R.O. aparece a firma de don Augusto González Besada, ministro de Facenda no autual gabinete, nacido en Pontevedra (Galicia) e preconizador dunha certa doutrina (?), pra engaiolare parvos, que se conoce co nome de "regionalismo ortodoxo". O 10 de outubro de 1917, os irmandiños xuntan a El Imparcial e a Gasset, o que chama o vello xornal da gasseteiría. E referíndose ó seu director din: "E na súa y-alma, D. Rafael Gasset, é o mesmo persoaxe que tomou de Costa unha ideya, pra non realizala endexamais; quen exerce derriba de Galicia un cacicato monstruoso, e derriba de Madrid unha influencia, non por debilitada menos nún".

Non todos, sen embargo, eran de opinión tan negativa. En varias ocasións, Luís Porteiro expresará a súa simpatía pola política hidráulica de Gasset, destacando o feito do seu vencello co espíritu de Costa, do que era, como sabemos, un dos seus grandes fanáticos: "Por fortuna se han planteado las bases para resolver el de la despensa que encaja en el Ministerio de Fomento, pues el hacendista ha de cimentar sus cálculos en la potencia económica del país, en la agricultura, industria y comercio". E xa concretando seguía: "Una de las bases, la más importante, es la política hdiráulica - ideal de Costa y Gasset, su discípulo - nueva orientación satirizada por ignorantes; no indica una reforma parcial en el orden agrario, es una ólocución trópica, especie de sinécdoque que expresa en cigra toda la política económica que cumple seguir a la nación para redimirse".

Entre o proxecto de Gasset e o de Costa, Porteiro establece unha conexión, que aquel recoñecía expresamente: "Basta ojear el proyecto del Sr. Gasset y compararlo con las conclusiones formuladas por Costa en la Asamblea Nacional de Productores, para ver clara la semejanza entre ambos trabajos; su objeto es el mismo: hacer que produzcan mucho más las tierras; abrir vías de comunicación para fomentar el comercio y la circulación de la riqueza, y facilitar el crédito agrícola". Referíndose a Costa, concretou Porteiro logo en Gasset os principios: "El proyecto del Sr. Gasset compendia sus aspiraciones y esperanzas; representa diez años de esfuerzos y de lucha contra la indiferencia y aún la burla de unos, y el excepticismo de los otros".

"CUADERNOS DE ESTUDIOS GALLEGOS", Tomo XLII, Fascículo 107, Santiago 1995. 


\section{III \\ UN INÉDITO DE ALFREDO BRAÑAS: \\ SOBRE AS POLÍTICAS ARANCELARIAS DO GOBERNO \\ ESPAÑOL E O PROXECTO DE TRATADO DE COMERCIO \\ COS ESTADOS UNIDOS POUCOS MESES ANTES DO DESASTRE DE $1898^{14}$.}

\section{AS RELACIÓNS ENTRE ESTADOS UNIDOS E ESPAÑA DESDE GALICIA}

A comenzos do ano 1898, o ministerio de Estado empezou a facelos preparativos para perfilalo tratado de comercio que pretendían concertalo Estado español e os Estados Unidos. No medio dunhas circunstancias tensas, por mor da insurrección cubana, e das mutuas acusacións que máis ou menos abertamente se facían ambolos dous gobernos, non faltaba quen coidaba que tal tratado non era máis que unha cortina de fume, baixo a que se acochaban as peores intencións bélicas. Comentando a situación, en carta particular a Xosé Canalejas, o embaixador español facía constar esta situación, ó tempo que facía xuicios despectivos sobre o presidente $\mathrm{Mc}$ Kinley, con motivo do seu mensaxe ó Congreso, do día 6 de decembro de 1897. Interceptada a carta, tales adxectivos contribuíron a fomentalo espíritu de hostilidade que, visiblemente, facía presaxiar xa daquela as peores consecuencias.

Se era unha cortina de fume ou era un medio máis para apacigualos ánimos e o desexo sinceiro de acabar con aquel clima de tensión, en plena insurrección cubana, o certo é que o Ministerio de Estado enviou un cuestionario ás Cámaras de Comercio, solicitándolles resposta a duas preguntas concretas, que se sintetizaban coas propias palabras do informe remitido pola de Santiago: "Dos extremos contiene la atenta comunicación de V.E., es a saber: $1^{\circ}$. Ventajas y concesiones que pueden realizarse en el comercio entre los Estados Unidos y la Península. $2^{\circ}$. Ventajas y concesiones que pueden obtenerse en el comercio entre la Península y los Estados Unidos respecto a la Isla de Cuba". O informe non está dividido en partes, xa que se trata dun relato corrido, pero, para unha mellor intelixencia,

\footnotetext{
${ }^{14}$ Revista da Federación Galega de Municipios e Provincias, número 7, Inverno 94-95.
}

"CUADERNOS DE ESTUdiOS GALlEGOS", Tomo XLII, Fasciculo 107, Santiago 1995. 
pode dividirse, segundo o esquema trazado polo cuestionario ministerial, en relacións comerciais entre Estados Unidos e a Península, como se lle chama a España, en relacións entre a Península e as colonias antillanas e en relacións directas entre as colonias antillanas e os Estados Unidos, de acordo cos tratados existentes entre ámbolos dous países soberanos.

Recibida a petición na Cámara de Comercio de Santiago, o presidente, Lucas de la Riva, despois de consultar a algúns directivos da entidade, optou por recabala axuda de Alfredo Brañas, encargándolle expresamente a redacción do conseguinte proxecto de informe que logo, sometido á xunta directiva, e sen retoque algún, foi remitido á Subsecretaría de Estado como expresión do criterio da propia organización mercantil compostelá. O manuscrito non se conservou entre os inéditos de Alfredo Brañas nin, polo momento, aparece entre os papeis da Cámara de Comercio. Consta, sen embargo, xa en letra redondiña, o escrito tal como foi remitido ó Ministerio.

En calquera caso, existe a seguridade da autoría de Alfredo Brañas, por así facerse constar na sesión do día 4 de abril de 1898. A acta da sesión é moi explícita sobre o asunto e non regatea adxectivos sobre os méritos do informe. Na sesión da Cámara de Comercio do 4 de abril de 1898, o presidente "expuso a la consideración de la Junta directiva la idea que le había sugerido con motivo del servicio prestado por el Señor Alfredo Brañas, catedrático de Economía y Hacienda de esta Universidad. Recordó a la reunión que el Ministro de Estado había invitado a las Cámaras de la Nación, a que informasen respecto al futuro tratado de Comercio con los Estados Unidos: considerando el asunto de trascendencia y de acuerdo con varios Sres. de la directiva se encargó la redacción del citado Informe al mencionado Sr. Brañas, que su probada competencia en asuntos de esa índole, era una garantía de éxito para el buen nombre de la Cámara, como así sucedió, pues el dictamen ha sido bien recibido por los inteligentes y calificado de luminoso"15.

A Cámara quixo agradecer dalgún xeito o esforzo do líder rexionalista $\mathrm{e}$, en consecuencia, aproveitando que presidía a procesión da Virxe das Dores, fixolle o presente que consta nas liñas seguintes: "La actitud del $\mathrm{Sr}$. Brañas para con la Cámara exigía que esta le demostrarse su reconoci-

\footnotetext{
${ }^{15}$ Cámara de Comercio de Santiago. Libro de Actas da Xunta directiva, da sesión expresada no texto.
}

"CUADERNOS DE ESTUdIOS GALLEGOS", Tomo XLII, Fascículo 107, Santiago 1995. 
miento y aprovechando la circunstancia de presidir dicho Sr. la procesión de la Virgen de los Dolores en nombre de la Cámara y oído el parecer de los miembros de la directiva que pudieron ser constituídos, se le obsequió con treinta libras de cera. La directiva vio con satisfacción las indicaciones del Sr. Presidente y por unaninimidad aprobó tal determinación"18.

A elaboración do informe entraba dentro da especialidade académica de Alfredo Brañas, se ben a súa formación intelectual e cultural eran moito máis extensas. Brañas era catedrático de Economía e Facenda da Facultade de Dereito de Santiago. Empezara como catedrático de Dereito Natural na Universidade de Oviedo, pero, por concurso de traslado, pasou a ocupala cátedra de Economía e Facenda Pública da Facultade de Dereito santiguesa no ano 1887. Coa súa teimuda paciencia, Alfredo Brañas acadou por ser unha autoridade en materia que inicialmente non constituía o foco das súas preocupacións intelectuais.

En materia económica publicou logo Brañas numerosos estudios, sobre todo de economía de Galicia, abrindo un capítulo de rexionalismo económico na historia do rexionalismo galego, lexitimado daquela sobre todo por argumentos de tipo histórico, antropolóxico e literario. Entre todos eles, destaca dun xeito moi especial La crisis económica en la época presente y la descentralización regional, discurso lído na inauguración do curso 1892-93, por ser unha obra auroral do rexionalismo galego. Máis doctrinal, por non decir apoloxética, é a Historia económica, publicada no ano 1894. En materia facendística, publicou Brañas Curso de Hacienda pública general y española no ano 1891, enriquecida logo por novas edicións. Esta obra, ten algúns aspectos que, para a mellor ambientación do Informe da Cámara, pode servir axeitadamente.

O informe de Brañas, asumido literalmente pola Cámara compostelá, caracterízase pola súa finalidade pragmática, por estar destinado a atendelo devandito cuestionario do Subsecretario de Estado e unha petición da Cámara de Comercio de Santiago, que, por certo, non sería a primeira nin a ultima. No seu famoso discurso académico, de 1893, expuxera o seu punto de vista xeral sobre os problemas entre o proteccionismo e o libre cambio, chegando a conclusión de que para Galicia e para España, procedía unha especie de proteccionismo moderado. Neste documento, en cambio, soamente podía contraerse ó obxecto da consulta feita pola Cámara de Comercio ante a invitación do Ministerio.

O documento é unha aportación máis dun capítulo da historia contemporánea galega pouco estudiado, como é o do desenvolvemento e as consecuencias do Desastre na vida galega, xa sometida daquela ós rigores dunha 
intensa sangría migratoria, na que precisamente destacaba Cuba como punto de destino. De todas maneiras, vale aclarar que son mínimas as mencións que se fan no informe sobre Galicia, xa que o destinatario era a Subsecretaría de Estado para un asunto moi concreto. Pero, hai unha que pode servir para historiar algo máis a tendencia, convertida practicamente en principio, dun modelo de librecambio para Galicia. Brañas dicía: "Desde luego, y en lo tocante a Galicia, convendría la rebaja del derecho aduanero para los maíces y sus harinas, base de la alimentación de nuestras clases agricultoras y ganaderas". Mentras que nos principios proteccionistas amparabanse rexións cerealísticas como Castela, algodoneiras de Cataluña, de industria do ferro no País Vasco e comenzaba a protección carbonífera de Asturias, para Galicia facíase necesario a libre importación do millo e da fariña, así como da folla de lata, necesaria para a industria conserveira. A cita, por pequena que sexa, é outro elemento máis que serverá para perfilala conciencia diferencial de Galicia, no futuro, estará vencellada ós aranceis do trigo e as carnes ${ }^{16}$.

\section{AS RELACIÓNS COMERCIAIS ENTRE ESPAÑA E OS ES- TADOS UNIDOS}

Comenzaba Brañas sinalando no informe que era a primeira vez que se tentaba de concertar un tratado internacional cos Estados Unidos en materia de comercio, xa que ata os aranceis de 31 de decembro de 1891 só tiña Estados Unidos o trato de nación máis favorecida, "cláusula antieconómica felizmente alejada para siempre de nuestra legislación arancelaria, según se lee en el preámbulo de la disposición antes citada". Dun xeito máis xeral, non limitado a tratados, convenios ou acordos de comercio, Brañas aseguraba que "el convenio de 1877 , modificado en 1882, referente a la extradición para la represión de delitos y a otros asuntos de carácter político fue el único ensayo de tratados internacionales que hemos intentado con los Estados Unidos". Esto non era, sen embargo, exactamente así, porque se fixeran habia tratados bilaterais o 25 de outubro de 1798, 11 de agosto de 1802, 22 de febreiro de 1819 ou de 17 de febreiro de 1834, sobre

\footnotetext{
${ }^{16}$ Gabriel TORTELLA: El desarrollo de la España contemporánea. Alianza Universidad Textos. Madrid, 1994.
}

"CUADERnOS DE ESTUdios GALlEGOS", Tomo XLII, Fascículo 107, Santiago 1995. 
todo relativos a cuestión de límites o de dereito de xentes. Quizáis o feito de ser tan concretos non invalidaba o aserto de Alfredo Brañas, dada a trascendencia específica que tiñan.

O que, en cambio, era xa máis importante para a mellor comprensión do Informe e, conseguintemente, do futuro tratado, era o acordo de réxime arancelario de 13 de febreiro de 1884 para mutuas concesións de avantaxes entre Cuba, Puerto Rico e os Estados Unidos, ou o convenio de supresión de dereitos diferenciais de arqueo ou impostos do 26 de maio de 1888, así como o real decreto de 28 de xullo de 1891, sobre franquicias e avantaxes entre os Estados Unidos e as Antillas españolas. Por outro lado, existían numerosos convenios multilaterais asinados polos dous países, como en correos, sistema métrico, protección en Marrocos ou comercio e civilización en Africa. Para os efectos do informe, non era cousa de dar polo miúdo un relato das relacións comerciais, multilaterais ou bilaterais, existentes entre España e os Estados Unidos, pero, certamente, son moitas máis que as que Brañas enumera.

Para delimitalo sentido da nova política americana, o Bill Mc Kinley de 1890, sobre protección da industria americana, era un preludio de como Estados Unidos tentaba de formular unha nova política comercial e de como os países europeos non eran xa capaces o seu impulso e a súa capacidade de liderazgo económico no mundo contemporáneo. El Imparcial, de Madrid, por exemplo, adicou varios artigos a ese Bill, o primeiro titulado El Bill Mac Kinley con relación a la península, publciado o día 5 de novembro; o día 21, publicouse o titulado El Bill Mac Kinley con relación a Cuba, onde ademais de refrexala protesta das Cámaras de Comercio cubanas, sinalaba que o cabotaxe era un desastre para Cuba. Na Gaceta de Galicia, o día 14 de novembro de 1890, adicouse un editorial a Los tratados comerciales, o que indica que existía inquedanza polo asunto.

A Cámara de Comercio xa daquela reaccionara contra o devandito Bill. Nunha sesión facíase constalo seguinte: "Dada cuenta de una Circular de la Cámara de Comercio de Sevilla manifestando los perjuicios que al comercio de importación se irrogarían de llevar a la práctica las disposiciones contenidas en la ley de los Estados Unidos de América "The MacKinley Bill", contra la cual habían ya reclamado Francia y otros Estados, exponiendo la necesidad deque se solicite del Excmo. Sr. Ministro de Estado entable las negociaciones necesarias para que los altos poderes de los Estados Unidos modifiquen, derroguen o determinen no aplicar a las procedencias españolas las disposiciones de "The Mac-Kinley bill", exigien-

"CUADERNOS DE ESTUdIOS GALLEGOS", Tomo XLII, Fascículo 107, Santiago 1995. 
do más garantías que el criterio de un Vista de Aduana y para defender los intereses de nuestro comercio de exportación a los puertos norte-americanos. Esta Junta abundando en los mismos sentimientos que expresa la aludida Circular acordó secundarlos en la forma reglamentaria y que se le comunique a la de Sevilla para su conocimiento". En carta de 21 de agosto de 1890, Lucas de la Riva remiteu, ó mesmo tempo, unha carta ó presidente da de Sevilla, especificando que estaban conformes en que se apoyase polos medios regulamentarios.

O informe de Brañas móvese xa en circunstancias áinda máis dramáticas. Comenza o seu informe, asumido literalmente pola Cámara, prantexando un problema de prudencia lexislativa. Coidaba que non era o momento de facer un tratado con Estados Unidos: "Basta lo sucedido para sospechar que los Estados Unidos non están hoy por hoy en condiciones de pactar con nosotros. Los Tratados de comercio deben ser garantías de paz, de buena amistad, y de cordialidad de relaciones. Y España y los Estados Unidos que desde hace muchos años vienen juzgando con opuesto criterio la insurrección cubana, que discurten sobre la procedencia de reclamaciones pecuniarias, que instruyen expedientes para averigurar si los españoles son responsables de delitos cometidos contra ciudadanos norteamericanos, no puede decirse que sean amigos de toda nuestra confianza, como podemos asegurarlo por ahora de Suecia y Norurega, Austria y aún Francia e Italia".

A Cámara, Alfredo Brañas, coidaban que era conveniente esperar a que acabase dunha vez a guerra de Cuba: "Cree esta Cámara de Comercio que mientras no se termine la guerra cubana, que no entren las Antillas en un periodo de completa tranquilidad, es prematuro aventurarse en un tratado de comercio, que puede ser contraproducente y acarrear complicaciones económicas más graves y trascendentales que las políticas y diplomáticas". Subsidiariamente dicía: “A lo sumo, y mientras la paz colonial no se restablezca, podrán entablarse negociaciones, discutiendose las bases del Tratado, difiriendo el canje de notas y las ratificaciones de ellas, hasta la completa pacificación de la Isla".

Desde moito antes da guerra hispanoamericana, as relacións entre Estados Unidos e España fóron tensa en moitas ocasións, sobre todo por mor de distintas accións relacionadas con Cuba, colonia do Imperio español. Se desde 1848 sucedíanse distintas accións, como ofertas de compra da Isla polos Estados Unidos, accións filibusteiras, etc., o anuncio do Bill Mac Kinley en 1890 complicou as cousas en materia comercial. Quedaba 
claro, desde aquel momento, que os Estados Unidos estaban dispostos a seguir unha política de protección arancelaria dos seus productos e que os países europeos non tiñan capacidade dabondo para facerlle fonte axeitadamente. As posibilidades de non mercarlle o petróleo, por exemplo, collendo o de Rusia, a que se refería El Imparcial, non tiña eco no ambiente europeo.

A Illa de Cuba era, por si mesma, un foco permanente de conflicto, con importantes efectos nas relacións comerciais. Por un lado, as relacións comerciais entre Cuba e Estados Unidos directamente afectaban as relacións entre España e Cuba. Pero,ademais, as políticas seguidas polo imperio español coa Illa de Cuba eran, ás veces, focos de conflicto en moitas ocasións, ata o punto que hai autores que explican a orixe e o desenvolvemento da insurrección por mor da política arancelaria seguida polo goberno español. Esta política consistía en favorecelos productos cataláns, para a exportación, gravando, en cambio, os productos das Antillas con fortes aranceis.

Desde 1895, a guerra de Cuba foi en aumento. De pouco valía a Constitución concedida en 1897, cun réxime autonómico, o primeiro existente na historia constitucional de España. O 1 de xaneiro constituíse o primeiro goberno autonómico en Cuba, baixo a presidencia de Galvez. O 25 de xaneiro, a presencia do Maine na Habana, e do Vizcaya en Nova Iorke, daban xa idea de como se desenvolvían as relacións entre España e os Estados Unidos. O ultimatum do 20 de abril, coa nova proposta de mercala Illa, intención manifesta xa desde 1848 , abocou logo na derrota e no Desastre, así configurado xa con maisculas na historia contemporánea de España.

Xa máis concretamente, para o caso de que non se atendera esta suxerencia, relativa á espera para facelo tratado, estimaban Brañas e a Cámara de Comercio que "para aplicar el principio de la reciprocidad sin alterar la $2^{\mathrm{a}}$ columna arancelaria, sería conveniente dividir la diferencia que hay entre los derechos de la primera columna y lasegunda en cuatro partes iguales, aplicando las rebajas en un 25, 50,75 ó 100 por 100 de la mencionada diferencia según la importancia de las concesiones que nos otorguen los Estados Unidos, y la clase de productos de la industria nacional, que haya de sufrir la concurrencia norteamericana en los mercados interiores, en los extranjeros y hasta en los antillanos".

A realidade deulle a razón a Alfredo Brañas, porque, meses máis tarde, cando aínda non tiveran nin tempo de lélos informes recibidos polo Minis-

"CUADERnOS DE ESTUdios GALLEGOS", Tomo XLII, Fasciculo 107, Santiago 1995. 
terio de Estado, estalou a guerra hispano-amaricana, o que significou a ruptura das relacións entre Estados Unidos e España. O tratado de París, no que interveu Uxío Montero Ríos, significaba a independencia para Cuba, o que facía xa innecesaria toda aquela política arencelaria que trabara as relacións entre as Antillas e España.

\section{O COMERCIO DE ESPAÑA CON CUBA E PUERTO RICO}

O comercio de España, ou da Península, como prefería chamarse, coas Antillas menores, concretamente, con Cuba e Puerto Rico, que eran as únicas colonias que se conservaban afectaba tanto ás relacións de España con cada unha das colonias, como as relacións comerciais que estas mantiveran con terceiros países. Para regulalas relacións entre a Península e as Antillas españolas, servía de base a Lei de 30 de xuño de 1882, pola que se igualaba o comercio entre os productos metrópolitanos e os procedentes das colonias españolas, pero na que se establecían excepcións sobre os productos precisamente coloniais, como o tabaco, augardente, azúcar, cacao, chocolate ou café. Os historiadores daquel momento están practicamente conformes en pensar que un dos factores que máis alporizou os ánimos na guerra cubana foi o trato dado por aquela lei, porque coidaban que fóra feita para primalos productos do comercio catalán, mentras que, sen reciprocidade algunha os productos coloniais eran gravados do xeito que para cada caso establecía a mesma lei.

Para as relacións directas entre Estados Unidos e as Antillas, o goberno español dictou tamén normas, reguladoras das políticas arancelarias a seguir entre Estados Unidos e eles, como xa vimos en parágrafo devandito. Como principios xerais, sobre o comercio con Cuba e Puerto Rico estimaba Brañas que debía basearse en dous principios: " 1 ". En el criterio de la reciprocidad limitada establecido por el régimen antiguo de 13 de febrero de 1884 y $2^{\circ}$. En un márgen de protección en favor de la industria nacional, recargando con un 30 ó 35 por 100 los principales artículos de importación norteamericana".

A primeira conclusión de Alfredo Brañas, asumida literalmente pola Cámara de Comercio de Santiago, era a seguinte: "El convenio comercial que se celebre entre la Isla de Cuba y los Estados Unidos debe fundarse en las franquicias otorgadas por el régimen arancelario de 1884 , limitándose todo lo posible la reciprocidad, y sin concederla jamás en sentido absoluto y para todos los artículos. Desde luego las ventajas de la libre

"CUADERNOS DE ESTUDIOS GALLEGOS", Tomo XLI1, Fascículo 107, Santiago 1995 
introducción enfavor de los productos antillanos debe extnderse a los azúcares, melazas, aguardientes, cacao y tabaco".

A segunda conclusión dicía: "En los aranceles antillanos debe haber un márgen de favor de 30 ó 35 por 100 para los siguientes productos, similares a los españoles: 1 . legumbres y frutas verdes y secas: $2^{\circ}$. Cebada, maiz, trigo y sus harinas: $3^{\circ}$. Conservas de carnes, pescados y frutas. $4^{\circ}$. Petróelo: $5^{\circ}$. Arroz con cáscara o sin ella. Los demás artículos manufacturados, similares a los de la Península deben ser gravados con un derecho protector minimun de un 20 por 100 y maximum de un 25 por 100 ".

Un ultimo apartado estaba adicado ó comercio ultramariño no informe de Brañas. Brañas dicía que, declarado o cabotaxe entre a Península e as Antillas pola disposición octava do Arancel vixente, estreitaronse os vencelos mercantís entre a producción nacional e os mercados antillanos: "Pero las profundas y graves alteraciones políticas de Cuba, la tendencia del consumo a preferir los productos similares extranjeros, y otras causas no menos importantes, hicieron fracasar muchas empresas, y mantienen enla actualidad ciertos temores y recelos respecto al tráfico con las dos islas antillanas".

Brañas explica que: "Los productores nacionales al exportar a Cuba y Puerto Rico lo hacen con intención convertir allí su dinero en productos coloniales de fácil y ventajosa venta en la Península. Pero la importación de los artículos de protección insular ofrece los inconvenientes de los recargos establecidos con carácter transitorio por las Leyes de Presupuestos de 1876-77 y 1878-79, que aumentan los gastos de un modo considerable. Urge reducir esos recargos transitorios. No se debe aspirar a otra cosa, porque pedir el cabotaje, como hicieron algunas Cámaras, es reclamar lo que ya tenemos. En este sentido, creemos que procede tomarse en cuenta la siguiente conclusión:

Debe dictarse una disposición, de acuerdo con el Gobierno local antillano, reformando los derechos actuales sobre azúcares, cacao, café y aguardiente. Podría llegarse a la supresión de los impuestos vigentes respecto al cacao y café, rebajando en un 50 por 100 los tipos que existen sobre los azúcares y aguardientes". O informe remata dicindo que: "Por lo que toca a los demás productos no hay inconveniente en que se fije un derecho recíproco de un tercio por ciento ad valorem a los productos peninsulares y antillanos". 


\section{O REXIONALISMO FISCAL A AUTONOMÍA DE CUBA E PUERTO RICO E OS PRIMEIROS MODELOS DA ORGANIZA- CIÓN AUTONÓMICA DO ESTADO ESPAÑOL}

No capítulo cincoenta do Curso de Hacienda pública general y española, Alfredo Brañas adica atención especial ás Facendas especiais, que concreta nas que se refiren ás colonias, ás provincias e ós municipios. Sen embargo, como tales especialidades, Brañas réstalles importancia, porque tales facendas ás que chaman tamén locais, "dado el sistema de centralización política y administrativa que hoy predomina en la mayor parte de las naciones, salvo en aquellas donde exista régimen federativo" non son máis que apéndices do réxime xeral. Referídose ás facendas coloniais, Brañas remachaba dicindo que "las leyes financieras de las colonias, provincias y municipios se hallan calcadas en las fundamentales del Estado nacional, y sólo de ellas difieren en su aplicación y práctica y en puntos de mero accidente y de poca trascendencia”. Co seu habitual optimismo, Brañas coidaba que "la reacción se está verificando en el orden científico" e que os enimigos da centralización eran cada vez os máis".

Con respecto á facenda colonial, Brañas describe sucintamente a de Cuba, a de Puerto Rico, a das Illas Filipinas e a da Colonia de Fernando Póo. En cada unha delas estudia os recursos, as contribucións e o creto público, para rematar en cada unha delas co persoal administrativo e financeiro. Pero, á altura en que redacta o Informe para a Cámarade Comercio, non deixa de ser curioso que garde silencio sobre as Constitucións autonómicas das illas de Cuba e Puerto Rico, aprobadas por reais decretos de 25 de novembro de 1897 , nas que o réxime comercial tiña un tratamento moi específico. Como rexionalista tiña que interesarlle moi concretamente aquela primeira experiencia sobre a autonomía política outorgada polo Estado español. Brañas reseñaba con algunha frecuencia os exemplos autonómicos que se ían producindo na realidade histórica do mundo enteiro, se ben no caso colonial español misturabanse otros conceptos, como o mesmo da decadencia e as causas que a produciran, así como significado dunha posible independencia encuberta e dos perigos que supoñía a súa implantación, materia na que o seu amigo Xoan Vázquez de Mella alzou bandeira contra a política gubernamental e concretamente contra a política de Sexismundo Moret.

O silencio parecía un camiño máis cómodo, agochado na expresión "graves alteraciones" ou na mención xeral de que "debe dictarse una disposición, de acuerdo con el Gobierno local antillano", que revelan que, aínda que non se extende sobre o asunto, tampouco omitía o papel que os 
textos legais asignaban ós gobernos de Cuba e Puerto Rico, tal como se plasmaban nas súas propias constitucións autonómicas.

Constitucións autonómicas que, por outra parte, contiñan algunhas previsións sobre materia comercial e arancelaria, pois, no fondo, estas eran as materias que interesaban dun xeito moi especial nas tensas relacións entre España e os Estados Unidos. Os artigos 37 e 38 regulaban a negociación dos tratados comerciais. Cando se debían a iniciativa do goberno insular ou do central, levaráse sempre por este, auxiliado por delegados especiais debidamente autorizados polo goberno colonial. De non intervilo goberno insular, comunicaránselle en tanto fóran leis do Reino, para que, nun periodo de tres meses, declarar se desexa ou non adherirse ás súas estipulacións.

Entre as competencias do parlamento insular figuraba a formación do Arancel e a designación dos dereitos que tiveran que pagalas mercancías, tanto á súa importación no territorio insular como á exportación do mesmo. Dun xeito transicional, ningún dereito, teña ou non carácter fiscal, podería ser diferencial en prexuicio da producción insular ou peninsular, formándose entre os dous gobernos unha lista de artigos de procedencia nacional directa e outra insular que debían ter trato privilexiado, sen que en ningún caso tales diferencias excederan do trinta e cinco por cento.

\section{V}

\section{MONTERO RÍOS E O TRATADO DE PARÍS}

\section{AS TENSIÓNS BÉLICAS E A FORMACIÓN DA COMISIÓN ESPAÑOLA}

O ambiente en que se desenvolvían os acontecementos era un ambiente bélico, coa gran expectativa creada polas posibilidades dunha paz digna e unha paz que paliara, aínda que fóra simbólicamente, as eivas da derrota e da frustración ${ }^{17}$. Desde o 14 de xullo de 1898 estaban suspendidas as

\footnotetext{
${ }^{17}$ Cámara Oficial de Comercio de Santiago. Libro de Actas da Xunta Directiva, 12 de xullo de 1898 , p. 65 , onde se menciona a recepción dun telegrama da de Vigo, para apoiar ó Goberno á procura dunha honrosa paz; Carlos SERRANO: Final del Imperio. España 1895-1898. Siglo veintinuo de españa editores. Madrid, 1984; Melchor FERNÁNDEZ ALMAGRO: . La reacción popular ante el desastre. Madrid, 1948.
} 
garantías constitucionais. O 26 de xullo, os Estados Unidos fixeron chegar las condicións en que podían acadarse a paz. Eran limitadas, e o vencedor non estaba disposto a negocialas. Sagasta consultou cos líderes políticos sobre os termos da negociación e da aceptación das condicións. O 11 de agosto acordouse comunicar a Estados Unidos a aceptación das condicións. No Senado, o día 5 de setembro, suscitouse debate tenso, pero, finalmente, foi aprobada o día 12 e promulgada o 16 a aceptación de tales condicións. Unha tensa expectación invadía o ambiente político, por-que o goberno non daba formado a Comisión española que debía concertala paz coa Comisión dos Estados Unidos. La Voz de Galicia calificouna como unha incógnita. Unha vez que fracasou no seu intento de que a oposición formara parte da Comisión, ó que se negaron Silvela e outros, Sagasta levou sixilosamente a escolleita e designación dos membros.

Finalmente, na Gaceta de Madrid do día 18 de setembro de 1898, publicaronse os nomes dos membros. Como presidente figuraba Uxío Montero Ríos, presidente do Senado. Díxose daquela que Montero Ríos fixo esforzos para non ir a París. A requerimentos da Raíña, como un servicio máis, parece que aceptou, seguro de que non era moito o que podía facer ante a contundencia das esixencias americanas. A prensa galega, e non galega, destacou o feito da aceptación por si mesmo, como un sacrificio e como un favor ó país. O Eco de Santiago felicitou a Montero por aceptar encargo tan complicado, cando outros, atentos sempre ós momentos felices, refugaban a encomenda. $\mathrm{O}$ xornal titula gráficamente $\mathrm{o}$ artigo como "Rapacidad escandalosa" e publicou o 10 de novembro 18 .

No Consello de ministros do 20 de setembro aprobaronse as instruccións a que debían axustarse nas negociacións. A Comisión dirixiuse á tódalas Corporacións e Sociedades mercantís, industriais e de todolos demais ordes que eran coñecidas en España. Só contestaron dezaoito cámaras e dez sindicatos, ligas ou gremios e algúns concellos, tal como explicou Montero Ríos nas súas conferencias da Unión Mercantil de Madrid ${ }^{19}$.

\footnotetext{
${ }^{18}$ Jesús FERNÁNDEZ Y GONZÁLEZ: Montero-Ríos. Santiago, 1920. Describe ampliamente os motivos polos que aceptan presidila Comisión española para negociar en París.

"Uxío MONTERO RÍOS: El Tratado de París. Madrid, 1904.
}

"CuAdernos DE estudios GAllegoS", Tomo XLII, Fasciculo 107, Santiago 1995. 


\section{A INFORMACIÓN DAS SESIÓNS DA COMISIÓN E ALGÚNS XORNAIS GALEGOS}

A prensa deu pouca información sobre o desenvolvemento das negociacións, porque era moi pouco o que se podía filtrar do acontecido en cada unha das sesións. Sobre todo, algúns dos xornais máis vencellados a Montero Ríos, ben pola circunstancia de editarse no pobo natal do líder ou por afinidade ideolóxica, daban despachos moi breves, algunha que outra información solta, era o único que ofrecían normalmente desde o primeiro de outubro, en que comenzaron. No primeiro dos artigos que adicou a Las conferencias de Paris, a Voz destacaba o pouco que se podía facer, porque non existía a posibilidade de discusión ante un interlocutor victorioso.

Tamén destacaron cando a impotencia fixo presa e Montero Ríos, ante a negativa da comisión americana, coidando mellor, en carta dirixida ó ministro, o 18 de outubro, que debía facerse unha acta en vez de un tratado, ó que se opuxeron os americanos. Como outra fórmula alternativa, noutro momento, propuxo un arbirtraxe, pero o seu goberno non foi partidario de tal proposta. $O E c o$ do 27 de outubro, sen embargo, dixo que Montero representa la esperanza del país. A Débeda de Cuba, as cubanas como se coñecían vulgarmente, era un dos grandes problemas co que tiña que afrontarse a comisión española, sendo este punto destacado pola Voz.

Noticias periféricas, non moita, chegaban de vez en cando sobre algúns aspectos relacionados coa actividade de Montero Ríos. Durante algún tempo corriu a voz de que se lle ofrecía un título nobiliario, pero que él, como sempre, non estaba disposto a aceptalo. Tamén ocupou algún espacio a agresión de que foi obxecto mentras paseaba polas rúas de París. Contouse nos xornais do 23 de novembro que Simón Rivas, ex propietario do teatro Príncipe Alfonso de Madrid, enimigo de Montero Ríos, por entender que fóra o causante da súa ruína, por un pleito levado contra él, foise a París e espallou un folleto contra o presidente da Comisión, distribuíndo entre españois residentes en París e, sobre todo, entre os comisionados españois e americanos. Montero envioulle unha carta, rebatindo as acusacións, que consideraba calumniosas. Simón Rivas esperouno, nun momento en que paseaba con Garnica, outro membro da comisión española, e intentou ceibarlle un bastonazo, evitando a agresión o outro comisionado e a policía que chegou axiña.

Non era a primeira vez que Simón Rivas intentou agredir a Montero Ríos. En marzo de 1992, cando no andar do Senado, intentou ceibarlle outro bastonazo, pero o senador logrou esquivalo golpe. Daquela explicouse 
que a causa fóra por mor dun pleito que durou doce anos e que significou unha victoria para o cliente de Montero. En calquera caso, a prensa do 13 de novembre de 1898, fixo pesquisas por medio dun amigo de Montero para coñela realidade dos rumores sobre a cuestión, pero éste dixo que se trataba dun rumor inexacto ${ }^{20}$.

Asinada a paz, o Goberno felicitou a Montero Ríos e o Eco de Santiago considerou o seu esforzo como un servicio inmenso a España. A Voz, o día 10 de decembro, dixo que Montero lograra coa sua inmensa habilidade facer constala protesta de España contra o tratado que inicuamente asinaban. Dicía que tal aceptación fixérase a despeito dos opoñentes, que servirá entre os antecedentes diplomáticos das negociacións, especificando que xa os feitos non tiñan remedio, queda como a voz da xusticia, coa protesta do vencido.

Chegou a España, por Irún, o 18 de decembro, e os xornalistas intentaron sacarlle algunha palabra sobre os acontecementos e os resultados da encomenda, pero non quixo falar nada. A cuestión política, a crise gubernamental, eran un novo capítulo ó que tería que afrontarse o líder santiagués. O primeiro era tentar de reconciliar a Sagasta con Gamazo, cousa difícil naquel momento, pero que, en calquera caso, él estaba ó lado do primeiro. Conferencias políticas a parte, a vista a Palacio, para informar á Raíña, foi mirada con moita expectación. O saír de Palacio, non quixo tampouco falar moito. Dixo soamente que explicou á Raíña con detimento os traballos feitos pola Comisión. En calquera caso, deixou claro que nada se falou sobre a cuestión política. Haberá que esperar ó ano 1904, para que, a aparte de algunha que outra entrevista, Montero ofreza unha pormenorizada descrición das interioridades dos traballos da Comisión.

\section{SALVADOR CABEZA DE LEÓN E O PATRIOTISMO DE MONTERO RÍOS}

Na velada necrolóxica que se celebrou o día 31 de xullo de 1916 en honor de Montero Ríos, no paraninfo da Universidade de Santiago, ademais de Cleto Troncoso, Lino Torre, Barcia Caballero e Armando Cotarelo

\footnotetext{
${ }^{20}$ Baldomero CORES TRASMONTE: Historia do Colexio de avogados de Santiago, citado.
}

"CUADERNOS DE ESTUdiOS GALlEGOS", Tomo XLIl, Fascículo 107, Santiago 1995. 
Valledor, tivo ocasión de facer uso da palabra don Salvador Cabeza de León, catedrático de Dereito Internacional na Facultade de Dereito o día 31 de xullo de 1916. O discurso de Barcia foi entre lírico e metafísico, o de Troncoso e Torre tiñan acento de exéxeses monterista, o de Cotarelo situabase entre erudito e poético. O de Salvador Cabeza foi unha análise do patriotismo de Montero Ríos, tanto ó aceptalo encargo para presidila comisión que debía negociar en París como polos resultados acadados. Era importante aquela testemuña, porque, sobre todo desde que Xoaquín Costa o fixera un dos grandes culpables do desastre, pesaban sobre Montero Ríos moi contradictorias opinións e xuicios moi dispares.

Entre Cabeza e Montero existían diferencias ideolóxicas e de partido que non impediron en aquela ocasión, como noutras, que o profesor de dereito internacional fixera o que entendía era xusto. Cabeza era rexionalista convencido, compañeiro de Alfredo Brañas na construcción do rexionalista galego;logo membro destacado da Unión Católica, sobre todo polos vencellos que o cinguían a Eduardo de Hinojosa e sempre vencellado a movementos de afirmación galega distintos ós programas ideolóxicos que sustentaban o pensamento e os sentimentos de don Uxío Montero Ríos.

Por eso, as palabras de Cabeza de León era especialmente importantes naquel momento en que se lle rendía homenaxe póstumo en Santiago a quen en vida non quixo homenaxes nin disticións: "El patriotismo de Montero Ríos estaba en el corazón, más que en los labios". Cabeza recordaba o sacrificio que supuxo para o líder santiagués aceptala presidencia da Comisión: "La aceptación que el mismo Montero calificó de "dolorosísimo encargo" puso a prueba no tan sólo sus sentimientos patrióticos, sino también su lealtad hacia la augusta dama que por entonces regía los destinos de la nación española. Manifestóse, pues, en aquella memorable ocasión, tan ardiente patriota, como cumplido caballero".

Tamén recordou Salvador Cabeza a fe do líder no pobo español despois da derrota: "Y no le faltó al inolvidable estadista, después de la catástrofe donde tantos valores morales y materiales se hundieron con espantosa rapidez, fe viva en los destinos de la nación española. “'Sursum corda!”, exclamaba al terminar las conferencias que acerca del Tratado de París pronunció en el Círculo madrileño de la Unión Mercantil", recollendo literalmente un dos parágrafos dos discursos de Montero. Para dicir logo: "En esas breves palabras encierra Montero Ríos un alta y provechosa lección para los gobernantes, expresada con la austera sencillez de que sabía re- 
vestir sus pensamientos. El patriotismo no impone deberes tan solo a los gobernados: alcanza también aquellos a los directores de la vida nacional, y con más fuerza, si cabe, que a los demás ciudadanos"21.

${ }^{21}$ Baldomero CORES TRASMONTE: A velada necrolóxica e o homenaxe da Universidade a Montero Ríos. «O Correo Galego», 26 de novembro de 1995.

"CUADERNOS DE ESTUdios GALLEGOS", Tomo XLII, Fascículo 107, Santiago 1995. 